\title{
With whom and in what is it better to save? Personal pensions in the UK
}

\author{
Anastasia Petraki \\ CGR and School of Management, University of Bath, UK \\ Anna Zalewska ${ }^{1}$ \\ CGR and School of Management, University of Bath, UK \\ CMPO, University of Bristol, UK
}

\begin{abstract}
April 2013
Abstract

This paper studies the relationship between fund and provider characteristics, and fund performance using a sample of 4,197 U.K personal pension funds operated by 35 providers over a 30 years' period $(1980-2009)$. The fund performance is measured on an annual basis (short-term) and over the whole period of fund operation (longterm). We find substantial differences in which factors explain performance in the short- and long-run and whether the performance is measured against T-bills or against fund chosen prospectus benchmarks. Although big providers tend to perform better than their prospectus benchmarks on an annual basis, they underperform T-bills over the period of fund life. The provider's extent of specialisation positively covaries with benchmark outperformance measured on an annual basis, but does not result in superior performance over funds' operational life. In the long-run, fund performance is positively associated with market concentration and negatively with fund age. We also find that the timing of opening funds matters for their long-term returns, and, on average, funds lose more money during bear markets than they make during bull markets. Policy implications are discussed.
\end{abstract}

Acknowledgement: The authors would like to thank an anonymous sponsor for funding Dr Anastasia Petraki's post-doctoral position at the Centre for Governance and Regulation (CGR), University of Bath which has made this research possible. We would also like to thank Morningstar for granting us access to their Morningstar Direct $^{\mathrm{TM}}$ database.

Keywords: pension funds, portfolio performance, Sharpe ratio, benchmark selection, portfolio risk

JEL Classification: G11, G18, G20, G23

\footnotetext{
${ }^{1}$ Corresponding/presenting author: School of Management, University of Bath, Bath BA2 7AY, UK, phone: +01225 384354; email: a.zalewska@bath.ac.uk
} 


\section{Introduction}

The factors explaining differences in performance across mutual funds have been researched on for decades. It is well documented that a range of individual funds' characteristics as well as some characteristics of fund families matter for mutual fund performance. Yet very little is known about the potential factors explaining performance of pension funds although the pension industry, whether in the U.S. or around the world, has a comparable, if not bigger, volume of assets under management (AUM) than the mutual fund industry, and its development and performance are potentially more important for economic and social reasons. Moreover, given the significant differences in the nature of mutual and pension funds' investments it can be expected that conclusions drawn for mutual funds do not hold universally for pension funds. This paper is the first to address the question of whether and, if yes, how the characteristics of pension funds and of their providers covary with fund performance. ${ }^{2}$ These questions are studied on a sample of 4,197 U.K. personal pension funds operating in the period 1980-2009.

The U.K. pension industry is one of the biggest in the world. It is ranked second in the OECD countries after the U.S. in terms of AUM, and fourth when measuring the ratio of the value of the AUM to GDP (Pension Markets in Focus 2011, OECD). In 2010 the U.K. funded pensions accounted for $\$ 1.9$ trillion of AUM, i.e., they were twice as big as mutual funds which by the end of 2010 had only $\$ 0.85$ trillion of AUM (ICI 2012). Yet, in spite of numerous steps by various British governments to encourage wider participation of the British population in funded pension schemes, participation ratios and reliance on personal savings at retirement remains relatively low. The Office for National Statistics (ONS) reports that in 2010 occupational pension schemes had 8.3 million active members which was "the lowest level since the 1950s". The participation in personal pension schemes has also declined in recent years (from 7.6 million active members in 2008 to just 6 million in 2010; Pension Trends, ONS, 2012).

The British experience is not unique. In spite of the commitment of numerous governments to shift the responsibility of old-age pension provision onto individuals,

\footnotetext{
${ }^{2}$ The only paper somewhat related is Ambachtsheer et al. (1998), but they look at a sample of 80 pension funds over a period of four years to assess whether internal asset management practices (such as a proportion of assets passively managed and the quality of fund's organisation design) are associated with better performance.
} 
and in spite of the significant financial and advisory support by the World Bank (the World Bank alone has spent over \$18bn on sponsoring the introduction of funded schemes in developing countries since the 1980s; World Bank, 2008), private pensions do not seem to be as attractive to the wide population as governments and regulators would wish for. In many countries, both developed and developing, the percentage of the population contributing to funded schemes is low (unless the schemes are compulsory, like e.g., in Denmark), and the level of contribution is lower than would be required to provide a comfortable retirement income. Given that funded pensions have become predominantly defined contribution (DC) schemes ${ }^{3}$ and the performance of capital markets has been rather unimpressive in the last decade, it is not surprising that contributors, who are the direct bearers of risk, do not seem to rush towards opening funded pension accounts, especially since unlike mutual funds' investments, the pension funds' investments are much harder to opt out from.

Policies designed to increase participation in personal pension schemes concentrate on making personal pension contributions quasi-compulsory (i.e., individuals have to opt out of them rather than enrol for them e.g., NEST in the U.K., KiwiSaver in New Zealand, TFR in Italy) and/or making them attractive through preferable tax treatment (e.g. the contributions to these schemes as well as the capital gains on private pension investments are subject to tax reliefs). Yet, it seems that little is known about the differences in the performance of individual pension providers, and in particular, the characteristics which may be associated with performance. Understanding the factors associated with fund performance is important for political, regulatory and social reasons. It is common to criticise ordinary people for being lethargic and reluctant to take responsibility for their financial future, yet, very little research is done to provide evidence which would support the individuals' decision making process and help develop a regulatory framework which would stimulate participation.

An overflow of opportunities can be sometimes more discouraging than a limited amount of them, and this might be the case of the personal pension industry in the U.K. In a 10 year period alone, i.e., 2000-2009, 9,404 new personal pension funds have been created. This means that on average over 900 new funds per year have been

\footnotetext{
${ }^{3}$ In the UK, a remarkable $67 \%$ of open DB schemes opened before the 1980 s, whereas only $4 \%$ opened during the 2000s. Similarly, more than half of closed DB plans were founded before 1980. On the other hand, only $1 \%$ of open DC schemes opened before 1980, with almost half opening in the 2000s (ONS, 2010).
} 
offered to potential contributors. ${ }^{4}$ Do these funds differ in their investment profile and investment strategies? How to distinguish amongst this flood of saving opportunities which providers and/or funds have been delivering good returns? Do funds who report good performance in annual reports perform well over long horizons?

Previous research on the performance of mutual funds sheds some light on those factors that may be expected to be associated with fund performance, e.g., family size, concentration, and specialisation (e.g., Massa, 2003; Chen et al., 2004; Ferreira et al., 2013). However, it is not obvious that features of providers and funds associated with the good mutual fund performance also characterise pension funds. This is because the pension fund and the mutual fund industries are very different both in their structures and objectives. ${ }^{5}$ For instance, the pension fund industry, unlike the mutual fund industry, consists of a relatively small number of big providers, and is expected to focus on long-term investments. Moreover, the mutual fund characteristics associated with good performance are found in research predominantly based on funds investing in domestic equity. Only a small fraction of pension funds invest exclusively in domestic equity, which casts an additional shadow over the direct transferability of the mutual fund industry characteristics to the pension fund industry.

While some factors with well documented statistical explanatory power in the case of mutual funds may become insignificant in the sample of pension funds, other factors may gain significance. For instance we conjecture that fund age may be important in the case of pension funds although it seems not to matter for mutual funds (Chen et al., 2004; Ferreira et al., 2012). In particular, using the career concern argument of Fama (1980) and Holmström (1999), we argue that younger funds may have more incentives to deliver higher returns than older funds. This may be additionally induced by a potential inability of contributors to monitor performance over long periods of time.

To our knowledge no research on the link between fund and fund family characteristics, and fund performance has been undertaken for pension funds. ${ }^{6}$ This research fills this gap in the literature by analysing a sample of 4,197 personal pension funds operated by 35 providers in the U.K. over a 30 year period $(1980-2009)$.

\footnotetext{
${ }^{4}$ This compares with 2,903 funds created in 1980-1999. These are the authors own calculations based on Morningstar Direct database.

${ }^{5}$ In some countries, like e.g., the USA, it is common for mutual funds to run pension accounts, but it is not a common practice that pension fund accounts are treated as forms of short-term investments.

${ }^{6}$ Petraki and Zalewska (2013) use a few provider characteristics as controls but do not focus on their explanatory power.
} 
Given that the U.K. personal pension fund industry is one of the oldest and biggest personal pension industries in the world, it offers an excellent sample to study the relationship between fund and provider characteristics, and performance.

This research is also the first to study whether there is a link between fund and provider characteristics for a broad range of asset classes. The existing research on mutual funds is predominantly restricted to equity funds with a focus on domestic equity. Such a restriction allows the use of asset pricing model based valuations to account for risk-return characteristics. However, given that the personal pension funds specialising in U.K. equities constitute less that $20 \%$ of all personal pension funds, ${ }^{7}$ and that it is common for pension policy holders to combine investments across different asset classes (e.g., NEST's default option is a combination of fixed income investments with a broader class of money market instruments and domestic as well as international equity), expanding beyond an analysis of U.K. equity funds is of paramount importance. This, however, brings to afore an old debate on what benchmarks are most relevant and informative, as using common stock market indexes is not suitable for non-equity portfolios, and, as Petraki and Zalewska (2013) show, even for equity portfolios. Moreover, it is also required to work with other than Jensen alpha-like measures of performance.

We use T-bills and primary prospectus benchmarks (PPBs) as reference levels of performance when assessing fund performance. The comparison of funds against PPBs which are used to attract potential contributors, report to existing contributors and assess performance of fund managers adds another dimension to the analysis making it richer and more informative. In our analysis we use 218 different PPBs as reported by individual funds.

Another novelty of this study is that it looks at factors that affect long-term and short-term performance of pension funds. ${ }^{8}$ In the case of mutual funds, and other investments with easy exit, there is no immediate need to account for long-term returns earned by funds. However, the situation is very different when it comes to pension funds. Here the distinction between short-term and long-term performance can be vital (Petraki and Zalewska, 2013).

\footnotetext{
${ }^{7}$ The U.K. equity funds constitute $32 \%$ of our sample, but in a sample of all funds, i.e., a sample extended to funds for which prospectus benchmark information is not available, they constitute $19.6 \%$ in 2009 (see Petraki and Zalewska (2013) for detailed statistics).

${ }^{8}$ In this paper long-term performance denotes performance based on compounded returns earned over the period of fund's operation (i.e., geometric returns), while compounded returns earned over calendar years are used to assess short-term performance.
} 
Our results suggest that there is some regularity in what factors matter for good performance, i.e., it is not all random which funds perform well and which do not, but the picture is rather complex. It seems that different fund and provider characteristics matter for long-term and for short-term performance, as well which measures of performance are used. Interestingly, we also find that there are substantial differences in what factors matter in explaining performance measured against T-bills, and against benchmarks chosen by the funds, i.e., the PPBs. We find that providers with a large market share in the fund's investment style earn superior cumulative excess returns. In other words, consistent with Ferreira et al. (2013) we find that higher concentration is associated with better performance. The extent of providers' specialisation in a fund's investment style helps to outperform PPBs on an annual basis only. However, the extent of specialisation does not help to earn superior longterm returns. We also find that the age of funds matters. Our results support the notion that younger funds perform better than older funds when the long-term (i.e., compounded) returns are analysed, although, it appears that it may take some time for young funds operating in a challenging environment (e.g., in emerging markets) to learn about market specifics and their initial performance may be weaker. We also find that pension funds opened during a bull/bear market underperform/outperform over the life of operation, and that funds seem to lose more during bear markets than they earn during bull markets.

These results have important implications for future research, pension contributors and policy design. We find that relying on short-term outperformance of the PPBs as a signal for positive long-term performance may be misleading. Bigger and more specialised providers seem to be better at outperforming the PPBs on an annual basis, but this does not lead to a superior long-term performance. This message should be clearly communicated to contributors and regulators. It strengthens arguments of Petraki and Zalewska (2013) against using the existing PPBs as informative reference points for assessing fund performance. Our finding of a negative relationship between fund performance and its age supports the view that contributors should be given more freedom in switching between funds. If funds feel under pressure of losing contributors, it may provide stimulus for maintaining efforts to maintain delivery of good financial results.

The rest of the paper is structured as follows. Section 2 summarises the literature on mutual funds and, based on this, formulates hypotheses for the personal pension 
industry. Section 3 describes the dataset, defines variables used in the empirical analysis, and provides basic descriptive statistics for these variables. Section 4 presents and discusses the results of the regression analysis. Section 5 concludes and outlines a few directions for future research.

\section{Literature review and hypotheses}

There are substantially more papers documenting mutual fund performance than addressing the factors that affect it. There is only a handful of studies that directly address the issue of which fund characteristics are associated with better performance. Indeed, it is more common to include mutual funds' characteristics as controls than focus on them.

The findings are quite diverse. For instance, Chevalier and Ellison (1999a), and Chen et al. (2004) find a negative relationship between fund size and performance while Golec (1996) and Otten and Bams (2002) document a positive relationship. Some studies also document that the expense ratio is negatively associated with performance (Golec, 1996; Chevalier and Ellison, 1999a; Otten and Bams, 2002; Chen et al., 2004; Prather et al., 2004; Ferreira et al., 2013). Choosing a fashionable fund name helps to attract new investors but does not necessarily affect performance (Cooper et al., 2005).

Fund family size, range of products offered and specialisation have been found to play a significant role in explaining performance of mutual funds (Guedj and Papastaikoudi, 2003; Massa, 2003; Chen et al., 2004; Nanda et al., 2004; Khorana and Servaes, 2012; Ferreira et al., 2013), but again it is not uniformly agreed whether these characteristics have a positive or negative association with performance. For instance, Massa (2003), Chen et al., (2004) and Khorana and Servaes (2012) argue that fund family size is positively related to fund performance due to the economies of scale and the greater resources that are available to larger families. However, Massa (2003) argues that size may become a negative factor if it, and not performance per $s e$, is used to attract investors and/or impacts negatively on competitiveness. He also argues that lack of specialisation in a particular investment style may have a negative impact on performance, although a wide range of products may attract more investors. Nanda et al. (2004) also show the positive effect of product differentiation but only in 
relation to how this increases the chance of creating a star fund. ${ }^{9}$ Finally, Ferreira et al. (2013) show that the market concentration, measured by the Herfindahl-Hirschman index, significantly positively covaries with performance at a country level.

Practically no research has been undertaken on the link between pension fund performance and fund/fund family characteristics. If fund and fund family characteristics enter regression specifications they are treated as controls rather than variables of interest (e.g., Petraki and Zalewska, 2013). In the case of pension funds, studying the relationship between fund and fund family characteristics, and performance may be additionally complicated by the fact that measuring pension fund performance seems more complicated than it is in the case of mutual funds. Petraki and Zalewska (2013) show that different patterns of pension fund performance can be observed depending on whether the performance is based on returns compounded over the fund's operational life (i.e., long-term) or annual (i.e., short-term) returns. Moreover, there are substantial differences across asset classes. Therefore, to account for these differences the relationship between the characteristics and performance should be studied for both long-term and short-term performance. It is both interesting and important to document whether the same fund and provider characteristics are associated with funds' abilities to both outperform their benchmarks on an annual basis and deliver good long-term returns in excess of Tbills. If good 'sprinters' have different characteristics than 'marathoners', than it may have strong policy implications.

At a provider level two characteristics are commonly found to be important in explaining mutual fund performance: size and specialisation. The size effect is explained by economies of scale and greater access to resources, which in the case of mutual funds may be important given the significant differences in size among mutual fund families. However, pension providers are quite big to start with, so although both economies of scale and greater access to resources may matter, their effect may be muted. Therefore, we expect that the statistical significance of the size variables will be low both for the short-term and long-term performance.

\footnotetext{
${ }^{9}$ One of the more recent branches of fund performance literature investigates spillover effects of a star fund within a fund family. Guedj and Papaskaikoudi, (2003) and Nanda et al. (2004) find that large families are more likely to have a star fund (they have more resources to allocate around in a way that ensures the creation of a star), and that having a star generates positive spillover effects within the family.
} 
On the other hand, the effect of specialisation may be quite well pronounced for pension funds given the complexity of pension funds' investments. In particular, if funds are focused on outperforming their PPBs, the extent of provider's specialisation in a given form of investment may be beneficial. This may be particularly visible in the short-run given that outperformance of PPBs seems to be attained by applying some 'investment tricks', like for example investing outside PPBs, rather than superior investment skills (Petraki and Zalewska, 2013). These 'investment tricks' may be less useful in retaining good performance in the long-run, hence it may be expected that specialisation will have lower explanatory power when fund performance is measured in the long-run.

A positive effect of concentration on mutual fund performance has been documented by Ferreira et al. (2013) although, as they argue, it might be more logical to expect that more competition increases pressure on funds to perform well. Given that the same argument could apply to the pension industry, it is interesting to test whether the relationship between concentration and performance is negative, as intuition would suggest, or positive, as the findings for the mutual fund industry indicate.

Motivation to deliver better results may also be related to fund age. Just as reputational concerns matter for individuals (Fama, 1980; Golec 1996; Holmström, 1999; Chevalier and Ellison, 1999a), they may matter for organisations, especially when there is little information about their past performance. The importance for young funds to perform well is also supported by the findings that investors seem more sensitive to performance news of young funds than to those of old funds (Chevalier and Ellison, 1997; Jylha, 2011) and that the probability of fund survival after a period of poor performance is significantly lower for young funds (Chevalier and Ellison, 1999b; Brown et al., 2001). However, Chen et al. (2004) and Ferreira (2013) find that fund age does not have statistical power in explaining U.S. mutual fund performance. This might be consistent with the fact that mutual funds attract active investors who tend to monitor the performance of their investments and face few exit restrictions. Hence mutual funds cannot afford to slow down in effort to satisfy their clients since they are free to join and leave at low cost. However, a different story might be in the case of pension funds. Here fund age might be important. Pension funds may have on average less financially literate investors which in combination with the long-term nature of pension investments and restrictions on 
opting out of them may result in pension funds' investors being more passive than mutual funds' investors.

When pension funds open they have to attract new contributors, and given that it is common for pension funds to be run by anonymous managers and not by financial gurus, it is fund (short-term) performance that can have a strong impact on how attractive a given fund is to potential contributors (the career concern argument of Fama (1980) and Holmström (1999)). Once the reputation of the fund is established, the value of new information decreases and so may do the monitoring pressure, resulting in a decline in the fund performance. If this is true we should observe a negative relationship between the fund's age and its long-term performance. The negative relationship between the long-term performance and age may also result from pension funds focusing on beating their assigned benchmarks in the short-run, e.g., this could happen if short-term investment strategies were not optimal from the long-term perspective. In addition, if pension funds concentrate on delivering good short-term performance, in particular in comparison with their benchmarks, then one could speculate that when short-term returns are analysed the relationship between age and performance might be positive. This could happen if the skill to outperform benchmarks grows with experience, and hence, time (Bauer et al., 2005). In summary, we expect that the relationship between performance and age may not be straightforward, but dependent on whether it is measured for the short- or the longterm performance, and whether the performance is measured against the PPBs or more 'objective' measures, like, for example, T-bills.

A career concern argument may also apply to providers entering a new market. If there is no, or limited, past information about the providers' past performance these new providers may be particularly focused on delivering superior results to establish their reputation. However, given that new providers can be expected to be smaller than well-established providers, the economies of scale argument may counteract or dilute this effect. Still, in the current world of high informational flows, it is rather unlikely that providers entering the U.K market will be completely unheard of. Some information about their past performance abroad or in different classes of financial services would be most likely available. Therefore, it is likely that it will be hard to observe clear cut results for providers' age. 


\section{Data and Variables}

We have collected data for 4,197 funds operated by 35 providers from the UK Life and Pension database by Morningstar Direct ${ }^{\mathrm{TM}}$ which include the fund's inception date, provider, classification of its investment style according to the Association of British Insurers (ABI), specification of a $\mathrm{PPB}$, and monthly return information from January 1980 till December 2009. Returns of PPBs have been calculated based on data collected from DataStream.

The ABI classification defines over 30 different sectors. Some of these sectors have very few funds and therefore, may not provide a meaningful comparison for sectors that have hundred or even thousands of funds. Having too many categories is also potentially troublesome and diverts attention from the main picture. Therefore, to make the sample numerically tractable we focus our attention on those ABI sectors that can be grouped into the following five investment styles: allocation (ALC), fixed income (FI), emerging market equity (EM-E), international equity (I-E), and UK equity (UK-E). ${ }^{10}$ Funds are classified as ALC if they invest in a mix of asset classes (e.g., $60 \%$ in equity of any category and $40 \%$ in FI). It should be mentioned at this point, that the ABI sector classification is based on the, so-called, primary investment focus, i.e., a fund belongs to a given $\mathrm{ABI}$ sector if at least $80 \%$ of its assets belong to the given ABI sector meaning that up to $20 \%$ of its assets can be invested outside its primary classification style.

In addition, we have also collected from DataStream a monthly time series of U.K. T-bills for the period 1980 -2009. We use the T-bills as a proxy for the risk free return.

\footnotetext{
10 The ALC funds consist of Balanced, Managed Caution, Managed Defensive and Managed Flexible funds. The FI funds consist of Global Fixed Interest, Global High Yield, Sterling Fixed Interest, Sterling Long Bond, Sterling High Yield, Sterling Corporate Bond, Sterling Other Fixed Interest, UK Index-Linked Gilts and UK Gilts funds. The EM-E funds include Global Emerging Market Equities funds. The I-E funds consist of Asia Pacific (excluding Japan), Asia Pacific (including Japan), Europe excluding UK, Europe including UK, Global Equities, Japan Equities, and North America funds. Finally, UK-E funds are UK All Companies, UK Smaller Companies and UK Equity Income funds. All the other ABI sectors that we drop from our sample add up to just 334 funds and come from a wide range of funds investing in money markets, real estate, etc.
} 


\subsection{Performance measures}

Previous research on pension fund performance is divided between papers using asset pricing based models as the method of valuation (e.g., Coggin et al., 1993; Brown et al., 1997; Blake et al., 2002), and using measures based on the Sharpe ratio (e.g., Antolin, 2008, Hinz et al., 2010, Petraki and Zalewska, 2013). The asset pricing based valuations require detailed information about the asset classes included in portfolios to ensure that meaningful benchmarks can be constructed to proxy for the market portfolio. ${ }^{11}$ The Sharpe ratio based valuation methods allow for comparison of more complex systems with less detailed information about individual fund asset allocation, but are not free of shortcomings (e.g., Lo, 2002; Antolin, 2008; Hinz et al., 2010)

Asset pricing models are not suitable for the data at hand. This is because we do not have detailed portfolio allocation information for individual funds, and in addition, funds of any type are allowed to invest outside the primary classification style, providing us with a strong argument against using common indexes as benchmarks (e.g., FTSE All Shares for funds specialising in U.K. equities). Moreover, even the PPBs cannot act as reliable market portfolios. This is because they refer only to the primary investment focus and funds are allowed to invest in assets and asset classes not included in their PPBs.

Bearing this limitation in mind the fund performance is assessed relative to T-bills and PPBs, with and without risk adjustment. The non-risk adjusted measures are the difference between fund returns and the yield of the U.K. T-bill, (denoted later as RTbill), and the difference between fund returns and the returns on the assigned PPB (denoted later as R-PPB). The corresponding risk adjusted measures are the Sharpe ratio (denoted later as SR) and the $\mathrm{M}^{2}$ introduced by Modigliani and Modigliani (1997). Each of these four measures is calculated for annualised returns compounded first, over a fund's operational life (geometric mean) resulting in a cross section, and then for each calendar year, which results in a panel structure of the data. Crosssection regressions based on annualised compounded returns will be denoted as ACR, and panel regressions based on annual returns will be denoted as AR.

\footnotetext{
${ }^{11}$ Issues with indexes as discussed by, e.g., Jensen et al., (1972), Modigliani and Pogue (1974), Blume and Friend (1975), Roll (1977), Roll and Ross (1994), and Ferson et al. (1999) remain valid.
} 
The summary statistics for the performance measures are provided in Table 1 . First, the statistics for the total sample (ALL) are provided. Then, the sample is divided into the five individual investment style groups.

$* * * * * * * * * * * * * *$ Table 1 here $* * * * * * * * * * * *$

The comparison of the ACR based performance measures (Panel ACR) with the AR based performance measures (Panel AR) shows that funds of all five investment styles perform on average worse in the long-run than in the short-run. This and the fact that the averages of the AR-based performance measure have much higher standard deviations than those of the ACR-based performance measure, may be, at least partly, attributed to the properties of the arithmetic and of the geometric averages. However, the differences observed among the investment styles may be a bit surprising. For instance, the UK-E funds earn on average only $0.39 \%$ above T-bills but $2.07 \%$ over their PPBs (the FTSE All Shares index is the PPB for the majority of these funds). Petraki and Zalewska (2013) suggest that this effect may result from funds investing outside their PPBs and the weak performance of the London Stock Exchange in 2008-2009.

\subsection{Providers' characteristics}

The Morningstar Direct ${ }^{\mathrm{TM}}$ database provides information on who is the provider of each fund. Using this information we have constructed the following provider characteristics on a monthly basis: size, share in each ABI investment style, degree of specialisation in each ABI investment style, and age. The summary statistics for these variables are shown in Table 2 . As in the case of Table 1 , first the summary statistics averaged across all funds are shown, then for each of the five individual investment groups. The panels with the cross-section averages and with panel data averages are denoted ACR and AR correspondingly to make them directly comparable with those presented in Table 1.

$* * * * * * * * * * * * * * * * * *$ Table 2 here $* * * * * * * * * * * * * * * * * * * *$ 
Given that no information about AUM is available, we calculate the provider's size, denoted later as Size, as the number (in 100's) of funds the provider operates (across all the ABI investment styles) at the end of the previous calendar year for panel data AR regressions and as the average of the month-end statistics over the period of the fund's operation for the ACR regressions. ${ }^{12}$ Table 2 shows that Size varies significantly across providers. Providers who just entered the market had zero funds under management at the end of the previous calendar year, while the biggest provider operated nearly 1,200 funds.

Using the number of funds rather than the AUM has also this benefit that it relaxes an issue of endogeneity. AUM may be directly affected by performance, i.e., good performance may lead to more cash inflows from investors, however, this may not be the case when the number of funds under operation is considered. This is because, if there are well performing funds, it is quite likely that any additional contributions will be paid to the existing schemes, rather than to competing schemes, even within the same provider. Therefore, the creation of new funds may be perceived more as a desire to expand business in a particular direction rather than the result of the superior performance of the existing schemes. However, to make sure that the impact of performance and size are not confused, in the panel data analysis we use the previous year-end statistics of Size. These can also be interpreted as the size at the beginning of each calendar year.

For every provider we also calculate their share in each individual ABI sector, Share-in-ABI, as the ratio of the number of funds within this ABI sector operated by the provider to the total number of funds within this $A B I$ sector operating in the market. As with Size, in the AR regressions Share-in-ABI is the end of a previous calendar year statistic, and in the ACR regressions Share-in-ABI is the average of the calendar month-end statistics over the period of the fund's operation. On average, Share-in-ABI is less than $8 \%$, however, it varies between $0 \%$ (for providers entering new investment styles) and $100 \%$.

\footnotetext{
${ }^{12}$ We have also calculated the log of the size, but given that the results for the log and the 'linear' size were practically identical, we focus on the 'linear' size. The provider characteristics are calculated on a sample of 10,086 funds, i.e., a full sample of personal pension funds. In the econometric analysis we use a sub-sample of 4,197 funds for which we had at least six months of observations and for which returns on the PPBs could be calculated.
} 
The degree of specialisation, ABI-share, of each provider in any of the ABI sectors is calculated as the ratio of the number of funds within this ABI sector to the number of all funds that the provider operates at the end of a previous calendar year in the panel, and the average of calendar month-end statistics in the cross-section. Again, there are substantial differences across providers. ABI-share varies between $0 \%$ and $63.92 \%$, with an average of less than $9 \%$.

Finally, we calculate provider's age, Prov-age, as the natural logarithm of the number of years elapsed since the inception date of the provider's first fund in the market plus one. Again, in the AR regressions we take the end-of-year observations and in the ACR regressions we use the natural logarithm of the provider's age at the end of $2009^{13}$, plus one. Table 2 shows that while on average providers have been present on the U.K. market for over 24 years $\left(=e^{3.22}-1\right)$, the body of providers is far from uniform, some operating for half a year and others operating for nearly 42 years.

Given that Prov-age and Size are correlated at $40 \%$ at the cross-section level and $51 \%$ at the panel level (Appendix 1 shows the pairwise correlations of all independent variables), Belsley et al. (1980) collinearity diagnostics are calculated to assess whether the variables can be used simultaneously is regression specifications. All the diagnostic statistics were safely below the critical values. ${ }^{14}$

\subsection{Funds' characteristics}

Individual funds are characterised by their $\mathrm{ABI}$ investment style and age. Each investment style is represented by a dummy equal to one if the fund belongs to this investment style and zero otherwise. Therefore, there are five mutually exclusive dummies: ALC, FI, EE, IE and UK-E, which refer to the allocation, fixed income, emerging market equity, international equity, and UK equity respectively.

\footnotetext{
${ }^{13}$ We have calculated provider's age as the average of the month-end observations as well but the results of the regression analysis are the same.

${ }^{14}$ Following Belsley et al. (1980) we calculate that (as long as we do not combine ABI-share with CR or HHI - see below for definition of these variables) mean VIF is 1.2 , and the condition number is 24.3, while the corresponding commonly accepted values are 10, and 30. In addition, the determinant is 0.6 , which is sufficiently away from zero to keep the variables in the same regression specification.
} 
For the panel analysis, the age of a fund, Fund-age, in any calendar year is measured as the natural logarithm of the number of years elapsed from the day of the fund's inception till the $31^{\text {st }}$ December of that year, plus one. For the cross-section analysis we take the natural logarithm of the fund's age at the end of 2009, plus one. Table 2 shows that the average Fund-age in the sample is just over 4 years, with the youngest funds operating for just half a year and the oldest ones for 30 years.

As discussed in Section 2, we aim to assess the impact of Fund-age on fund performance. It is a mathematical property of the geometric mean that it does not exceed the arithmetic mean. The side effect of this mathematical property is that one can expect to find older funds performing worse than younger funds, only because in the case of older funds the average is taken over a longer period of time. Although the correlation between the geometric mean and the arithmetic mean returns is very high (98\%), to sidestep this potential bias we also use the arithmetic mean returns when testing the impact of Fund-age on performance in the long-run. The results obtained for the arithmetic mean returns are treated as a robustness test, and for this reason are not fully reported to save space.

\subsection{Market conditions}

Performance of funds may also be related to market competitiveness (e.g., Khorana and Servaes, 2012; Ferreira et al., 2013) and the general performance of markets (e.g., Klein and Rosenfeld, 1987; Petraki and Zalewska, 2013). To test for the significance of these factors we define two measures of market competition in each fund's ABI sector: the Concentration Ratio (CR) and the Hirschman-Herfindahl Index (HHI). Additionally, we control for bull and bear markets' conditions. We extend the analysis to all bull and bear periods (not just the financial crisis 2007-2009) to gain a better understanding of the impact of good and dire periods for fund performance.

The CR and the HHI are defined for each ABI sector in each month using the providers' market shares in that sector. The CR is based on the market shares of the three largest providers in each ABI sector. We use the year-end observations of the $\mathrm{CR}$ and the HHI for the AR regressions. The ACR regressions use the average of the month-end observations. The HHI observations are divided by 100 for scaling purposes. Table 2 shows substantial differences across the styles' level of 
competitiveness, CR varies between $20 \%$ and $100 \%$, and $\mathrm{HHI}$ varies between $4 \%$ and $100 \%$.

It is important to note that the pairwise correlations between CR and $\mathrm{HHI}$ are $91 \%$ and $84 \%$ for the ACR and the AR data respectively. In addition, both measures of market concentration are highly correlated with Share-in-ABI $(67 \%, 72 \%$, for the ACR data, and 72\%, 77\% for the AR data). Therefore, to avoid multicollinearity these three variables are used alternately in the regression analysis.

There are many methods to identify bear and bull periods (e.g., Fabozzi and Francis, 1977; Klein and Rosenfeld, 1987; Maheu and McCurdy, 2000; Chordia et al., 2001; Capocci et al., 2005; Gonzalez et al., 2005; Chen, 2009; Hibbert and Lawrence, 2010). Although the individual methodologies may differ in details, they are all focused around a common characteristic: bear markets are associated with negative returns and above average volatility, whereas bull markets are associated with positive returns and below average volatility. We also adopt these characteristics and given that in our sample funds invest in a wide range of markets, the bull and the bear periods are defined by the return-risk characteristics of the individual funds' PPBs. More precisely, the Bear-market dummy is equal to one in a given calendar year if the average monthly return of the PPB is negative and the PPB's standard deviation of the monthly returns for this year is above the average of the yearly PPB's standard deviations in the period 1980-2009. The Bull-market dummy equals one in a given calendar year, if the PPB's average monthly return is positive and the standard deviation of the monthly returns for that year is below the 1980-2009 average. Given that these two dummies have a correlation coefficient of -0.53 we use them alternately in the panel regression specifications.

In the cross-section regressions it is impossible to use time dummies, so we construct two additional dummies, Bear-born and Bull-born, which control for the market conditions at the time when a fund started to operate. More precisely, the Bullborn dummy is equal to one if a fund opened during a bull market, i.e., its Bull-market dummy is equal to one at the year of fund opening, and zero otherwise. Similarly, Bear-born is equal to one if a fund opened during a bear market, i.e., its Bear-market dummy is equal to one at the year of fund opening. 


\section{Regression Analysis}

\subsection{Determinants of Performance Based on ACRs}

We start the analysis from assessing the explanatory power of the providers' and funds' characteristics, as defined in Section 3. Table 3 shows the first set of regressions. The first four columns (Panel A) show the results of what we call the basic regression specification, i.e.,

$$
\begin{gathered}
\text { Performance }_{i}=\alpha_{1}+\alpha_{2} \text { Size }_{i}+\alpha_{3} \text { Share-in-ABI }_{i}+\alpha_{4} \text { ABI-share }_{i}+\alpha_{5} \text { Prov-age }_{i} \\
+\alpha_{6} \text { Fund-age }_{i}+\alpha_{7} \text { ALC }_{i}+\alpha_{8} \text { EM-E }_{i}+\alpha_{9} \text { I- }_{i}+\alpha_{10} \text { UK-E } \\
i
\end{gathered}
$$

where, for each fund i, Performance denotes the annualised R-Tbill, R-PPB, $\mathrm{M}^{2}$ or SR. Size measures the average absolute size of fund i's provider, Share-in-ABI and ABI-share measure its provider's average relative size and specialisation in the corresponding ABI sector, respectively. The averages are calculated over the period of fund i's operation. Prov-age and Fund-age denote the age of fund i's provider and of the fund itself as of December 2009. ALC, EM-E, I-E, and UK-E, are the investment style dummies, i.e., FI is used as the default category. ${ }^{15}$ The following eight columns show regressions in which Share-in-ABI is replaced by CR (Panel B) and HHI (Panel C), which we constructed to control for market concentration. As discussed in Section 3.4 the three measures of market concentration (Share-in-ABI, $\mathrm{CR}$, and $\mathrm{HHI}$ ) are used alternately due to their high pairwise correlations. All the regressions are clustered by the provider to control for heteroscedasticity.

$* * * * * * * * * * * * * *$ Table 3 here $* * * * * * * * * * * *$

Table 3 shows that the regressions explaining the PPB-related performance have low explanatory power, and only one coefficient is statistically significant (the ALC Dummy). The model works much better in explaining the excess returns and Sharpe ratios. The $\mathrm{R}^{2}$ increases to a respectable level $(11 \%)$ and several estimates of the

\footnotetext{
${ }^{15} \mathrm{FI}$ is chosen as the default category because investments in fixed income securities are considered to be a lower-risk/lower-return option. Moreover, according to the new regulation of NEST contributors are not encouraged to invest in portfolios consisting of fixed income securities only, but the proportion of pension investments allocated to fixed income securities increases with contributor's age.
} 
coefficients are statistically significant. Share-in-ABI is highly statistically significant and an increase of $10 \%$ in $\mathrm{ABI}$ market share ( $8 \%$ is the mean) results in the average additional $2.3 \%$ return over the T-bill rate and 0.38 higher SR. The inclusion of CR and HHI give very similar results, i.e., the more concentrated the ABI sector is, the better the performance of funds of this sector. Regardless of whether Share-in-ABI, $\mathrm{CR}$ or $\mathrm{HHI}$ are used the coefficients estimated for the other variables are very similar, and the explanatory power of the models remains practically unchanged, therefore in the further part of the analysis we show results for Share-in ABI only as it is directly linked to the individual providers.

Fund-age is another variable with statistically significant coefficients (all at 1\%). The negative sign of the coefficients suggests that performance declines with age. Using the estimated coefficients for R-Tbill we can calculate that the difference between one year old and five years' old funds is approximately $6.6 \%$, and between five years' old and ten years' old funds is $3.6 \%$. The corresponding differences for the Sharpe ratio would be about 1.4 and 0.8 . The declining rate of change is a consequence of the log-transformation of age. ${ }^{16}$

Interestingly provider's size, specialisation in a given ABI style, ABI-share, and Prov-age do not have statistical power in explaining performance. ${ }^{17}$ The coefficients estimated for the investment style dummies show that the excess returns of the EM-E and of the E-I are statistically higher than those of the FI funds (default category), and the UK-E funds have statistically significantly lower SR than the FI funds.

These results are consistent with several of our hypotheses, and, in particular, the high significance of the coefficients estimated for Fund-age supports the argument of career concern. However, it might be premature to conclude that fund performance declines with age because the effect we observe might be driven by other factors that covary with age. For instance, if in more recent times funds of a particular investment style have been created and it happens that this style performs better than other investment styles, then the superior performance of this style might drive the result. To control for this possibility we add investment style dummies interacted with Fundage to the regression specification.

\footnotetext{
${ }^{16}$ We have also used linear, square root and quadratic functions of age. The fit of the model was strongest for the log function. The significance of the estimated coefficients was similar.

${ }^{17}$ Although Prov-age is not particularly highly correlated with Size we repeated the regressions without the latter to ensure that this result is not driven by the presence of Size. We do not report these regressions because the omission of Size did not affect the results.
} 
Another possibility might be that the opening of funds coincides with particular market conditions, i.e., one could expect that providers try to time the opening of new funds, and, in particular, try to open funds when the markets are doing well and the general attitude towards investing is positive. To formally test whether the market conditions impact on fund performance we add the Bull-born and Bear-born dummies to the regression specifications.

Table 4 shows the results of specification (1) enriched by interactions between Fund-age and the investment style dummies, and two dummies which control for whether a fund was opened during a bull (Bull-born) or a bear (Bear-born) market. Overall, the results are similar to those presented in Table 3 (e.g., Share-in-ABI and Fund-age matter), but there are also a few interesting changes.

$* * * * * * * * * * * * * *$ Table 4 here $* * * * * * * * * * * *$

First, the inclusion of Bull-born and Bear-born dummies, as well as the interactive effects doubles the $\mathrm{R}^{2}$ of the regressions that use PPB related performance measures and results in statistical significance of several estimates of the coefficients. The coefficient estimated for Fund-age is significant at 5\% and positive in the regressions with R-PPB as the dependent variable. This suggests that older funds are better than younger funds in outperforming their PPBs in nominal terms. The $\mathrm{M}^{2}$ regressions, on the other hand, show that this outperformance does not persist once risk is accounted for. However, the coefficients estimated for the interactive terms of ALC, and EM-E are 10\% significant and negative suggesting that there is some weak evidence that the allocation funds and those specialising in emerging markets equity perform better when they are young.

In the R-Tbill regressions the interaction of Fund-age is only significant for I-E (10\% and 5\%) and ALC (10\%). Interestingly, the positive coefficients are estimated for the interactions of Fund-age with the I-E and the UK-E funds when SR is the dependent variable. This indicates that the risk-adjusted returns of these styles decline slower with fund's age than they do for the FI funds. Based on this evidence we can conclude that it is not the opening of a particular investment style that drives the results, because a negative association of fund age remains true for three investment styles. 
The coefficients estimated for the Bear-born and the Bull-born dummies indicate that funds opened during a bear market outperform their PPBs on average by $1.17 \%$ and $1.32 \%$ annually in absolute and risk adjusted terms respectively. Funds opened during a bull market underperform T-bills on an annual basis by an average 5.47\%, and in risk-adjusted terms they underperform the PPBs by $0.75 \%$ (small, but still statistically significant). They also have 1.15 lower Sharpe ratios. This average underperformance of the Bull-born funds, and especially the break in the pattern of PPB outperformance may suggest that pension fund managers invest in portfolios riskier than their PPBs when markets are doing well, and subsequently lose more money when the markets reverse. To test whether the Bull-born funds are more risky than their PPBs we performed a t-test for the hypothesis that the standard deviations of the funds and of the PPBs have the same mean. Indeed, the t-tests reveal, that the Bull-born funds are statistically significantly more risky than their PPBs at 5\%, while the other funds (Bear-born and opened during "normal" times have statistically indistinguishable risk from their PPBs). This suggests that Bull-born funds may be less diversified and/or overinvest in higher risk assets in comparison to the other funds. Given that pension funds may have limited ability to reorganise their portfolios (e.g., they are restricted by their prospectus' declared investment style and benchmark) a subsequent reversal of the market conditions leaves them particularly vulnerable and prone to underperformance.

Finally, one could argue that the negative relationship between Fund-age and performance results from using the geometric averaging. To address this concern we repeat the analysis using the arithmetic average returns to calculate the performance measures. To save space Table 5 shows the regression results for the specifications shown in Table 4 only. These are also the toughest tests, as they control for the alternative explanations of Fund-age and performance relationship.

$* * * * * * * * * * * * * *$ Table 5 here $* * * * * * * * * * * *$

The results, are very similar to those presented in Table 4. Most importantly, the coefficients estimated for Fund-age continue to be negative and significant at $1 \%$ for R-Tbill and SR. The coefficients estimated for $\mathrm{M}^{2}$ are insignificant as previously, and those of R-PPB are positive and significant at $5 \%$. 


\subsection{Determinants of Performance based on ARs}

As discussed in Section 2 it could be expected that long-term and short-term properties of pension funds' investments differ. In this section we break up the performance of the whole period of operation into calendar years to investigate the annual characteristics of the sample. However, before the regression results for the panel data are presented some econometric issues need to be addressed.

The Hausman test (Hausman, 1978) indicates that there are strong unit effects, the Lagrange multiplier test (Baum, 2001) detects strong group-wise heteroscedasticity, and the Wooldridge test (Drukker, 2003) indicates strong first-order autocorrelation. Furthermore, our panel can also have spatial correlation, i.e. correlation between the cross-sections of the panel (Wooldridge, 2002), but we cannot formally test for it (as in Hoyos and Sarafidis, 2006) given that the panel is unbalanced and has many crosssections. Nevertheless, since spatial correlation is considered common for panels with more cross-sections than time periods, as it is in our case, we need to control for it as well as heteroscedasticity and autocorrelation. We do this by using the Hoechle (2007) method which calculates Driscoll-Kraay standard errors (Driscoll and Kraay, 1998) for balanced and unbalanced panels. Indeed, if we control only for heteroscedasticity and autocorrelation we get much lower standard errors so our standard errors from the Hoechle method are robust to all three 'evils': heteroscedasticity, autocorrelation, and spatial correlation. In addition, we employ fixed effects in order to obtain unbiased coefficients (Wooldridge, 2002).

We start with a specification similar to (1) but without investment style dummies (because we control for the fund fixed effects and these dummies are time-invariant). Tables 6 and 7 Panel A are equivalent to Tables 3 and 4 respectively. Table 7 Panel B provides an additional robustness test by introducing year dummies. ${ }^{18}$

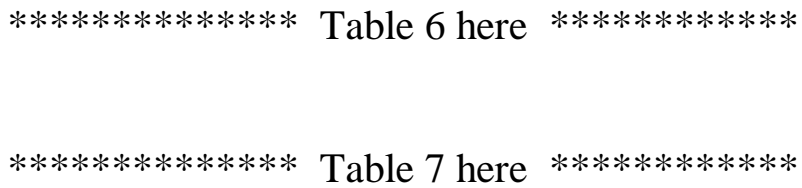

\footnotetext{
${ }^{18}$ We do not show the results for the arithmetic returns because on a yearly basis the geometric and the arithmetic mean returns are almost identical and very highly correlated $(99.7 \%)$.
} 
Tables 6 and 7 show that Size does not have strong statistical power in explaining the annual performance. The coefficients estimated for Size are significant and positive for $\mathrm{M}^{2}$ only. They are $5 \%$ significant for the basic specification, and when the bear market conditions are controlled for. The significance drops to $10 \%$ when the bull market dummy is used. The effect of Size is small given that an extra 100 funds increases $\mathrm{M}^{2}$ by about $0.53 \%$ per annum only. Consistent with the results presented in section 4.1, Share-in-ABI (and equivalently CR and HHI) is statistically significant only for R-Tbill and SR. This means that although the relative size on the market covaries with the performance, it does not help to outperform the PPBs. This result is consistent with Massa (2003).

In contrast with the ACR results the degree of specialisation in the fund's ABI investment style, ABI-share, is consistently significant across all panel specifications for R-PPB and $\mathrm{M}^{2}$. In particular, an increase of $10 \%$ in specialisation of fund's $\mathrm{ABI}$ sector leads to a $1.8 \%-2.3 \%$ increase in $\mathrm{R}-\mathrm{PBB}$ and a $1.4 \%-2.2 \%$ increase in $\mathrm{M}^{2}$ per annum. In other words, specialisation helps to beat the PPBs on an annual basis, even though it does not help to outperform them or earn positive excess returns on a long-term compounded basis.

The coefficient estimated for Prov-age is significant and negative in several regression specifications for $\mathrm{M}^{2}$ (Table 6 and Table 7 Panel A and B). To test the robustness of this finding, i.e., whether this result is true or spurious due to unobserved factors that change with time, we add year fixed effects. We do this by including dummies for each of the years 1990-2009 and leaving out the 1980s period as a reference point. ${ }^{19}$ The results (Table 7 Panel C) confirm our suspicion. The significance of the coefficients estimated for Prov-age disappears.

In contrast with the ACR results, the coefficients estimated for Fund-age became insignificant when year fixed effects are controlled for in addition to the interactions between Fund-age and investment style dummies (Table 7 Panel C). Moreover, Table 7 suggests that the positive and significant coefficients presented in Table 6 are driven by the EM-E funds, and by the I-E and the ALC funds in the regressions for $\mathrm{M}^{2}$. This result, although it contrasts with the ACR results, does not necessarily contradict the

\footnotetext{
${ }^{19}$ We do not put in individual dummies for the years in the 1980 s since only 662 observations, i.e. $2.63 \%$ of our sample comes from this period and so, having all year dummies from 1981 creates a multicollinearity problem. We have tried controlling for years 1981-2009 (with 1980 being our reference year) but we get rather erratic results for the year dummies although the results for the other variables are very similar to those with the 1990-2009 dummies.
} 
career concern argument. Bauer et al. (2005) show that ethical mutual funds (a relatively new style) have significantly lower initial performance than more 'conventional' funds, and that the difference in performance gradually diminishes. They argue that ethical funds have a "catching-up phase, possibly due to learning". This may also apply here in the sense that the EM-E funds initially underperform because they have more to learn than other funds investing on more 'conventional' markets, and/or this process of learning is longer. However, the fact that they eventually do catch up (no underperformance in a longer run) may indicate that there was an increased effort at the beginning. The positive coefficient estimated for the interaction of Fund-age with the ALC funds and with the I-E funds may also be consistent with the hypothesis of learning given that allocation calls for understanding of many different asset classes, and international equity requires an acquisition of regional knowledge.

Finally, the coefficients estimated for the Bear-market and the Bull-market dummies indicate that the funds do not outperform their PPBs when markets are declining or rising. The negative and significant at $1 \%$ coefficient estimated for the Bull-market dummy in the regression for R-PPB implies that funds perform worse than their PPBs during 'good times'. However, their excess returns and Sharpe ratios are higher during the bull times and lower during the bear times. The coefficients estimated for Bear-market are about twice as big (in absolute terms) as the coefficients estimated for Bull-market, which may be an indication of poor timing skills documented in previous research (e.g. Henriksson, 1984; Coggin et al., 1993; Daniel et al., 1997; Cuthbertson et al., 2008).

\section{Conclusions and Discussion}

In a world of increasing reliance on funded pensions to finance retirement there is surprisingly little known about the factors determining performance of pension funds. This paper is the first one to address the question of whether funds' and their providers' characteristics have explanatory power in explaining pension fund performance. Given that pension funds are allowed to invest up to $20 \%$ in assets outside their main investment asset class, performance is not measured within an asset pricing model framework but in relation to T-bills (via excess returns and Sharpe 
ratios) as well as in comparison to prospectus assigned benchmarks (PPBs), i.e., benchmarks used to advertise funds to potential clients and to report results to the existing contributors. Using PPBs allows the distinction between objective measures, such as excess returns and Sharpe ratios, and more subjective ones, i.e., in relation to a benchmark chosen by a fund. We assess the performance - fund/provider characteristics relationship using annual returns and returns compounded over the period of a fund's operation to address the question of whether there are differences in what characteristics are associated with good performance in short run and in the long run.

Our results indicate that different fund and provider characteristics matter for longterm and for short-term performance. Moreover, the results are sensitive to whether the performance is measured against T-bills, or against the PPBs. In brief, we find that characteristics associated with outperformance of the PPBs on annual basis have no explanatory power in explain long-term performance against T-bills, and vice versa. More specifically, we find that, while the extent of provider's specialisation in the fund's investment style is positively associated with the ability to outperform the PPBs on an annual basis, it is the providers with a large market share in the fund's investment style who outperform T-bills. In contrast with the previous research on mutual funds, we do not find evidence that absolute size of providers is associated with good performance. Indeed, we find some weak evidence that cumulative returns of big providers are lower than those of T-bills. This may be a specific characteristic of the personal pension industry, but it may also result from the fact that, unlike the papers studying mutual funds, we measure size by the number of funds and not by the volume of AUM.

Age appears to be a complex factor. While the age of the providers does not seem to matter for performance, the age of funds has significant explanatory power, although the sign of the impact is not clear. Using life-long compounded returns we find that younger funds earn better excess returns and have higher Sharpe ratios than older funds. This effect is weaker for the UK-E and the I-E funds. In contrast, younger funds are not as good as old funds in earning higher returns than their PPBs in nominal terms. However, after adjusting for risk, i.e., in the $\mathrm{M}^{2}$ terms, this effect disappears, and, consistent with the results for the T-bills, the ALC and the EM-E equity funds have a negative fund age - performance relationship. 
The analysis based on annual returns shows the opposite effect, i.e., the fund age performance relationship is positive for PPB related measures (no relationship is detected for the excess returns and Sharpe ratios). However, adding interactive terms shows that the result is driven by the EM-E, the I-E and the ALC funds. This finding is consistent with the argument of initial learning which may be more pronounced in a more knowledge and information intensive investment environment.

Finally, the results indicate that there are strong and potentially long-lasting consequences of when funds have been created. For instance, it matters whether funds have been opened during bull or bear markets with the latter ones performing statistically significantly better than the former ones. This seems intuitively obvious given that it is better to buy when assets may be cheap rather than when they may be overpriced, but it is a bit surprising that it has a long-lasting effect. This result may be partly driven by the timing of the sample. Although the sample starts in 1980, a sizable proportion of the sample funds was created in 2006 and 2007 when the markets were doing well. Consequently, these funds might have experienced heavy losses during the financial crisis which drives the results. It also seems that funds lose more money during bear times than they make during bull times.

So how do these results inform real life decisions? Do they offer any valuable insight for ordinary contributors and regulators? From a contributors' perspective it is clear that going for big pension providers does not guarantee good long-term performance. Even if funds offered by bigger providers are better at outperforming their prospectus benchmarks than funds offered by smaller providers, they earn returns lower than T-bills over the period of the funds' operation. Relying on specialisation can also lead to disappointment. Greater specialisation seems to positively covary with the ability to perform better than the PPBs on an annual basis, but this does not translate into the superior performance over the funds' operational life. The analysis seems also to suggest that it may be financially more rewarding to invest in younger rather than older funds, although it might be a good idea to wait a while to let funds investing in emerging markets equity to pass the "catching up phase'. Finally, it seems that it is a bad idea to invest in funds opened when markets are booming.

From the perspective of regulators it is important to fully acknowledge the role of the PPBs in the process of motivating and monitoring pension fund managers. It also seems important to make switching providers and funds less costly for contributors. If 
fund performance is age related and it is the young funds that deliver better performance, contributors should be free to leave the fund they have been contributing to if they feel it is losing its 'investment steam'. Such freedom to leave may be a more lasting stimulus for funds' managers to deliver good results than an introduction of any 'easy-to-beat' PPB. This freedom to exit should be accompanied by a full disclosure of long-term returns earned by funds in comparison with returns earned on alternative investments other than the PPBs.

This is a first step towards understanding the relationship between fund/provider and performance characteristics. More research on time patterns of performance across different investment styles, as well as the choice and role of prospectus benchmarks is needed.

\section{References}

Ambachtsheer, K., R. Capelle, and T. Sheibelhut, 1998, "Improving pension fund performance." Financial Analysts Journal 54(6): 15-21.

Antolin, P. (2008). "Pension fund performance." OECD Working Papers on Insurance and Private Pensions.

Bauer, R., K. Koedijk, and R. Otten, (2005). "International evidence on ethical mutual fund performance and investment style." Journal of Banking \& Finance 29(7): 1751-1767.

Baum, C. F. (2001). "Residual diagnostics for cross-section time series regression models." The Stata Journal 1(1): 101-104.

Belsley, D. A., E. Kuh, and R.E. Welsch (1980). "Regression diagnostics", Wiley Online Library.

Blake, D., B. N. Lehmann, and A. Timmermann (2002). "Performance clustering and incentives in the UK pension fund industry." Journal of Asset Management 3(2): 173.

Blume, M. E. and I. Friend (1975). "The asset structure of individual portfolios and some implications for utility functions." The Journal of Finance 30(2): 585603. 
Brown, G., P. Draper, and E. McKenzie (1997). "Consistency of UK pension fund investment performance." Journal of Business Finance \& Accounting 24(2): 155-178.

Brown, S. J., W. N. Goetzmann, and J. Park (2001). "Careers and survival: Competition and risk in the hedge fund and CTA industry." The Journal of Finance 56(5): 1869-1886.

Capocci, D., A. Corhay, and G. Hübner (2005). "Hedge fund performance and persistence in bull and bear markets." The European Journal of Finance 11(5): 361-392.

Chen, J., H. Harrison, M. Huang, and J.D. Kubik (2004). "Does fund size erode mutual fund performance? The Role of Liquidity and Organization." The American Economic Review 94(5): 1276-1302.

Chen, S.-S. (2009). "Predicting the bear stock market: Macroeconomic variables as leading indicators." Journal of Banking \& Finance 33(2): 211-223.

Chevalier, J. and G. Ellison (1997). "Risk taking by mutual funds as a response to incentives." The Journal of Political Economy 105(6): 1167-1200.

Chevalier, J. and G. Ellison (1999a). "Are some mutual fund managers better than others? Cross-sectional patterns in behavior and performance." The Journal of Finance 54(3): 875-899.

Chevalier, J. and G. Ellison (1999b). "Career concerns of mutual fund managers." The Quarterly Journal of Economics 114(2): 389-432.

Chordia, T., R. Roll, and A. Subrahmanyam (2001). "Market liquidity and trading activity." The Journal of Finance 56(2): 501-530.

Coggin, T. D., F. J. Fabozzi, and S. Rahman (1993). "The investment performance of U.S. equity pension fund managers: An empirical investigation." The Journal of Finance 48(3): 1039-1055.

Cooper, M.J., Gulen, H. and Rau, P.R. (2005) "Changing names with style: mutual fund name changes and their effects on fund flows." Journal of Finance, 60(6): $2825-2858$

Cuthbertson, K., D. Nitzsche, and N. O’Sullivan (2008). "UK mutual fund performance: Skill or luck?" Journal of Empirical Finance 15(4): 613-634.

Daniel, K., M. Grinblatt, S. Titman, and R. Wermers (1997). "Measuring mutual fund performance with characteristic-based benchmarks." The Journal of Finance 52(3): 1035-1058. 
Driscoll, J. C. and A. C. Kraay (1998). "Consistent covariance matrix estimation with spatially dependent panel data." The Review of Economics and Statistics 80(4): 549-560.

Drukker, D. M. (2003). "Testing for serial correlation in linear panel-data models." Stata Journal 3(2): 168-177.

Fabozzi, F. J. and J. C. Francis (1977). "Stability tests for alphas and betas over bull and bear market conditions." The Journal of Finance 32(4): 1093-1099.

Fama, E. F. (1980). "Agency problems and the theory of the firm." Journal of Political Economy 88(2): 288-307.

Ferreira, M. A., A. Keswani, A.F. Miguel and S.B. Ramos (2013). "The determinants of mutual fund performance: A cross-country study." Review of Finance 17(2): 483-525.

Ferson, W. E., S. Sarkissian, and T. Simin (1999). "The alpha factor asset pricing model: A parable." Journal of Financial Markets 2(1): 49-68.

Golec, J. H. (1996). "The effects of mutual fund managers' characteristics on their portfolio performance, risk and fees." Financial Services Review 5(2): 133.

Gonzalez, L., J. G. Powell, J. Shi, and A. Wilson (2005). "Two centuries of bull and bear market cycles." International Review of Economics \& Finance 14(4): 469-486.

Guedj, I. and J. Papastaikoudi (2003). "Can mutual fund families affect the performance of their funds?" EFMA 2004 Basel Meetings Paper.

Hausman, J. A. (1978). "Specification tests in econometrics." Econometrica 46(6): 1251-1271.

Henriksson, R. D. (1984). "Market timing and mutual fund performance: An empirical investigation." The Journal of Business 57(1): 73-96.

Hibbert, A. M. and E. R. Lawrence (2010). "Testing the performance of asset pricing models in different economic and interest rate regimes using individual stock returns", ePublications@bond.

Hinz, R. P., R. Heinz, P. Antolin, and J. Yermo (2010). "Evaluating the financial performance of pension funds", Washington, D.C., World Bank Publications.

Hoechle, D. (2007). "Robust standard errors for panel regressions with cross-sectional dependence." Stata Journal 7(3): 281-312.

Holmström, B. (1999). "Managerial incentive problems: A dynamic perspective." The Review of Economic Studies 66(1): 169-182. 
Hoyos, R. E. and V. Sarafidis (2006). "Testing for cross-sectional dependence in panel-data models." Stata Journal 6(4): 482.

ICI (2012). "2012 Investment Company Fact Book; A review of trends and activity in the U.S. investment company industry."

Jensen, M. C., F. Black, and M.S. Scholes (1972). "The capital asset pricing model: Some empirical tests." Michael C. Jensen, Studies in the Theory of Capital Markets, Praeger Publishers Inc., 1972.

Jylha, P. (2011). "Hedge fund return misreporting: Incentives and effects." SSRN eLibrary.

Khorana, A. and H. Servaes (2012). "What drives market share in the mutual fund industry?" Review of Finance 16(1): 81-113.

Klein, A. and J. Rosenfeld (1987). "The influence of market conditions on eventstudy residuals." The Journal of Financial and Quantitative Analysis 22(3): 345-351.

Lo, A. W. (2002). "The Statistics of Sharpe Ratios." Financial Analysts Journal 58(4): 36-52.

Maheu, J. M. and T. H. McCurdy (2000). "Identifying bull and bear markets in stock returns." Journal of Business \& Economic Statistics 18(1): 100-112.

Massa, M. (2003). "How do family strategies affect fund performance? When performance-maximization is not the only game in town." Journal of Financial Economics 67(2): 249-304.

Modigliani, F. and L. Modigliani (1997). "Risk-adjusted performance." The Journal of Portfolio Management 23(2): 45-54.

Modigliani, F. and G. A. Pogue (1974). "An introduction to risk and return: Concepts and evidence." Financial Analysts Journal 30(3): 69-86.

Nanda, V., Z. J. Wang, and L. Zheng (2004). "Family values and the star phenomenon: Strategies of mutual fund families." The Review of Financial Studies 17(3): 667-698.

OECD (2011). "Pension Markets in Focus 2011."

Office for National Statistics (2012). Pension Trends. URL:

http://www.ons.gov.uk/ons/rel/pensions/pension-trends/chapter-6--privatepensions--2012-edition-/art-pt2012ch6.html\#tab-abstract [22 March 2013]

Otten, R. and D. Bams (2002). "European mutual fund performance." European Financial Management 8(1): 75-101. 
Petraki, A. and A. Zalewska (2013). "Jumping over a low hurdle: Personal pension fund performance." SSRN Working Paper.

Prather, L., W. J. Bertin, and T. Henker (2004). "Mutual fund characteristics, managerial attributes, and fund performance." Review of Financial Economics 13(4): 305-326.

Roll, R. (1977). "A critique of the asset pricing theory's tests Part I: On past and potential testability of the theory." Journal of Financial Economics 4(2): 129176.

Roll, R. and S. A. Ross (1994). "On the cross-sectional relation between expected returns and betas." The Journal of Finance 49(1): 101-121.

Wooldridge, J. (2002). "Econometric analysis of cross section and panel data", The MIT press.

World Bank (2008). "Pension lending and analytical work at the World Bank: FY2002-07", Discussion Paper No. 0811, Social Protection and Labor Group. 
Table 1. Summary statistics of the performance measures used in the regression analysis. ACR denoted the statistics obtained for annualised compounded returns, and AR denotes the statistics obtained for annual average returns.

\begin{tabular}{|c|c|c|c|c|c|c|c|c|c|c|}
\hline & \multicolumn{5}{|c|}{ Performance based on ACR } & \multicolumn{5}{|c|}{ Performance based on AR } \\
\hline & Obs. & Mean & $\sigma$ & Min & Max & Obs. & Mean & $\sigma$ & Min & $\operatorname{Max}$ \\
\hline \multicolumn{11}{|l|}{ ALL } \\
\hline R-Tbill, \% & 4197 & 2.13 & 11.32 & -25.79 & 109.76 & 23740 & 2.72 & 22.46 & -83.00 & 251.14 \\
\hline R-PPB, \% & 4197 & 2.14 & 4.95 & -37.62 & 38.55 & 23740 & 2.69 & 10.18 & -65.25 & 154.33 \\
\hline $\mathrm{M}^{2}, \%$ & 4197 & 2.59 & 4.95 & -39.28 & 45.44 & 23740 & 3.30 & 9.92 & -40.74 & 52.70 \\
\hline SR & 4197 & 0.50 & 2.38 & -4.38 & 18.40 & 23740 & 0.71 & 4.74 & -22.01 & 13.83 \\
\hline \multicolumn{11}{|l|}{ ALC } \\
\hline R-Tbill, \% & 337 & 1.75 & 7.85 & -10.31 & 46.45 & 1814 & 1.97 & 18.22 & -52.68 & 81.95 \\
\hline R-PPB, \% & 337 & 3.16 & 3.68 & -10.04 & 16.17 & 1814 & 3.08 & 8.44 & -45.49 & 33.29 \\
\hline $\mathrm{M}^{2}, \%$ & 337 & 3.66 & 4.61 & -8.57 & 34.84 & 1814 & 3.88 & 8.79 & -40.74 & 52.70 \\
\hline SR & 337 & 0.67 & 2.77 & -2.65 & 18.40 & 1814 & 1.07 & 4.59 & -8.95 & 13.83 \\
\hline \multicolumn{11}{|l|}{ FI } \\
\hline R-Tbill, \% & 630 & 2.01 & 6.72 & -15.19 & 50.08 & 3586 & 1.29 & 12.11 & -52.44 & 81.58 \\
\hline R-PPB, \% & 630 & 2.10 & 5.24 & -23.70 & 34.87 & 3586 & 3.48 & 10.46 & -65.25 & 69.28 \\
\hline $\mathrm{M}^{2}, \%$ & 630 & 2.74 & 5.28 & -24.03 & 28.89 & 3586 & 3.55 & 9.05 & -40.74 & 52.70 \\
\hline SR & 630 & 0.89 & 2.79 & -3.52 & 16.82 & 3586 & 0.25 & 4.71 & -22.01 & 13.83 \\
\hline \multicolumn{11}{|l|}{ EM-E } \\
\hline R-Tbill, \% & 158 & 11.10 & 18.61 & -20.21 & 109.76 & 590 & 17.83 & 42.91 & -83.00 & 109.45 \\
\hline R-PPB, \% & 158 & 1.58 & 5.48 & -29.22 & 25.46 & 590 & 1.87 & 10.23 & -56.04 & 34.94 \\
\hline $\mathrm{M}^{2}, \%$ & 158 & 2.77 & 5.97 & -9.66 & 26.53 & 590 & 4.46 & 11.26 & -40.74 & 52.70 \\
\hline SR & 158 & 1.39 & 2.21 & -1.85 & 11.56 & 590 & 2.64 & 5.36 & -11.90 & 13.83 \\
\hline \multicolumn{11}{|l|}{ I-E } \\
\hline R-Tbill, \% & 1708 & 2.82 & 12.20 & -20.29 & 83.38 & 10061 & 2.87 & 23.48 & -68.27 & 251.14 \\
\hline R-PPB, \% & 1708 & 2.06 & 4.44 & -29.09 & 38.55 & 10061 & 2.36 & 9.70 & -53.39 & 154.33 \\
\hline $\mathrm{M}^{2}, \%$ & 1708 & 2.54 & 4.62 & -23.48 & 45.44 & 10061 & 2.92 & 9.40 & -40.74 & 52.70 \\
\hline SR & 1708 & 0.49 & 2.18 & -3.76 & 17.25 & 10061 & 0.71 & 4.01 & -22.01 & 13.83 \\
\hline \multicolumn{11}{|l|}{ UK-E } \\
\hline R-Tbill, \% & 1364 & 0.39 & 10.90 & -25.79 & 79.51 & 7689 & 2.35 & 23.32 & -69.12 & 103.77 \\
\hline R-PPB, \% & 1364 & 2.07 & 5.58 & -37.62 & 22.27 & 7689 & 2.81 & 8.97 & -50.92 & 65.58 \\
\hline $\mathrm{M}^{2}, \%$ & 1364 & 2.30 & 5.13 & -39.28 & 27.31 & 7689 & 3.58 & 8.99 & -40.74 & 52.70 \\
\hline SR & 1364 & 0.19 & 2.27 & -4.38 & 17.07 & 7689 & 1.03 & 4.76 & -22.01 & 13.83 \\
\hline
\end{tabular}


Table 2. Summary statistics of the continuous independent variables used in the regression analysis. ACR refer to crosssection regressions and AR refer to the panel regressions.

\begin{tabular}{|c|c|c|c|c|c|c|c|c|c|c|}
\hline . & \multicolumn{5}{|c|}{$\mathrm{ACR}$} & \multicolumn{5}{|c|}{$\mathrm{AR}$} \\
\hline & Obs. & Mean & $\sigma$ & Min & Max & Obs. & Mean & $\sigma$ & Min & Max \\
\hline \multicolumn{11}{|l|}{ ALL } \\
\hline Size & 4197 & 5.00 & 2.77 & 0.08 & 11.65 & 25290 & 3.70 & 2.82 & 0.00 & 10.85 \\
\hline Share-in-ABI & 4194 & 7.13 & 5.14 & 0.10 & 60.67 & 25264 & 7.68 & 7.41 & 0.00 & 100.00 \\
\hline ABI Share & 4194 & 8.26 & 7.39 & 0.13 & 59.73 & 25183 & 8.76 & 8.72 & 0.00 & 63.92 \\
\hline Prov-age & 4197 & 3.36 & 0.49 & 1.32 & 3.76 & 25292 & 3.22 & 0.48 & 0.41 & 3.76 \\
\hline Fund-age & 4197 & 1.69 & 0.64 & 0.41 & 3.44 & 25292 & 1.66 & 0.72 & 0.41 & 3.44 \\
\hline HHI & 4194 & 33.13 & 8.72 & 22.71 & 98.46 & 25268 & 34.74 & 11.70 & 20.76 & 100.00 \\
\hline $\mathrm{CR}$ & 4194 & 7.49 & 3.64 & 4.64 & 72.47 & 25268 & 8.18 & 6.33 & 4.04 & 100.00 \\
\hline \multicolumn{11}{|l|}{ ALC } \\
\hline Size & 337 & 4.84 & 2.94 & 0.35 & 11.65 & 1814 & 3.28 & 2.80 & 0.00 & 10.85 \\
\hline Share-in-ABI & 336 & 7.31 & 4.04 & 0.34 & 16.60 & 1813 & 7.53 & 5.02 & 0.00 & 25.00 \\
\hline ABI Share & 336 & 12.39 & 16.92 & 0.84 & 59.73 & 1805 & 17.15 & 20.97 & 0.00 & 63.92 \\
\hline Prov-age & 337 & 3.42 & 0.35 & 1.32 & 3.76 & 1814 & 3.23 & 0.46 & 0.55 & 3.76 \\
\hline Fund-age & 337 & 1.72 & 0.60 & 0.45 & 3.21 & 1814 & 1.59 & 0.64 & 0.41 & 3.21 \\
\hline $\mathrm{HHI}$ & 336 & 7.16 & 2.16 & 4.64 & 12.66 & 1813 & 7.76 & 2.70 & 4.30 & 21.40 \\
\hline $\mathrm{CR}$ & 336 & 31.97 & 8.30 & 22.71 & 53.26 & 1813 & 34.54 & 10.13 & 21.19 & 68.97 \\
\hline \multicolumn{11}{|l|}{ FI } \\
\hline Size & 630 & 4.98 & 2.67 & 0.11 & 11.57 & 3586 & 3.57 & 2.70 & 0.00 & 10.85 \\
\hline Share-in-ABI & 628 & 8.85 & 6.81 & 0.50 & 60.67 & 3584 & 10.07 & 10.50 & 0.00 & 100.00 \\
\hline ABI Share & 628 & 3.66 & 6.34 & 0.22 & 59.25 & 3571 & 4.59 & 7.34 & 0.00 & 63.92 \\
\hline Prov-age & 630 & 3.39 & 0.45 & 1.32 & 3.76 & 3586 & 3.23 & 0.48 & 0.41 & 3.76 \\
\hline Fund-age & 630 & 1.67 & 0.68 & 0.41 & 3.40 & 3586 & 1.72 & 0.76 & 0.41 & 3.40 \\
\hline $\mathrm{HHI}$ & 628 & 10.15 & 5.99 & 4.96 & 72.47 & 3584 & 11.20 & 10.47 & 4.97 & 100.00 \\
\hline CR & 628 & 40.32 & 10.68 & 23.63 & 98.46 & 3584 & 42.17 & 14.48 & 23.65 & 100.00 \\
\hline \multicolumn{11}{|l|}{ EM-E } \\
\hline Size & 158 & 6.11 & 2.90 & 0.73 & 11.38 & 590 & 4.87 & 3.11 & 0.00 & 10.85 \\
\hline Share-in-ABI & 158 & 11.74 & 10.03 & 0.65 & 58.27 & 590 & 15.74 & 16.89 & 0.00 & 100.00 \\
\hline ABI Share & 158 & 3.48 & 1.51 & 1.07 & 5.65 & 589 & 3.54 & 2.13 & 0.00 & 19.05 \\
\hline Prov-age & 158 & 3.40 & 0.40 & 1.39 & 3.76 & 590 & 3.31 & 0.37 & 0.69 & 3.76 \\
\hline Fund-age & 158 & 1.41 & 0.55 & 0.61 & 3.17 & 590 & 1.40 & 0.62 & 0.41 & 3.17 \\
\hline $\mathrm{HHI}$ & 158 & 14.15 & 6.75 & 9.29 & 60.08 & 590 & 17.88 & 13.75 & 9.14 & 100.00 \\
\hline $\mathrm{CR}$ & 158 & 51.83 & 10.23 & 43.86 & 90.49 & 590 & 56.69 & 15.91 & 43.75 & 100.00 \\
\hline \multicolumn{11}{|l|}{$\mathrm{I}-\mathrm{E}$} \\
\hline Size & 1708 & 4.98 & 2.77 & 0.08 & 11.65 & 10061 & 3.64 & 2.80 & 0.00 & 10.85 \\
\hline Share-in-ABI & 1708 & 6.42 & 3.75 & 0.10 & 18.40 & 10061 & 6.46 & 4.41 & 0.00 & 23.08 \\
\hline ABI Share & 1708 & 6.98 & 3.51 & 0.13 & 19.66 & 10025 & 6.95 & 3.62 & 0.00 & 21.82 \\
\hline Prov-age & 1708 & 3.35 & 0.49 & 1.32 & 3.76 & 10061 & 3.21 & 0.48 & 0.55 & 3.76 \\
\hline Fund-age & 1708 & 1.70 & 0.67 & 0.41 & 3.37 & 10061 & 1.70 & 0.73 & 0.41 & 3.37 \\
\hline $\mathrm{HHI}$ & 1708 & 6.50 & 1.24 & 4.95 & 17.89 & 10061 & 6.70 & 1.64 & 4.41 & 22.68 \\
\hline $\mathrm{CR}$ & 1708 & 29.79 & 4.56 & 24.38 & 56.56 & 10061 & 30.83 & 5.89 & 22.55 & 66.67 \\
\hline \multicolumn{11}{|l|}{ UK-E } \\
\hline Size & 1364 & 4.95 & 2.75 & 0.10 & 11.65 & 7687 & 3.78 & 2.84 & 0.00 & 10.85 \\
\hline Share-in-ABI & 1364 & 6.64 & 4.69 & 0.38 & 31.04 & 7686 & 6.88 & 6.27 & 0.00 & 80.00 \\
\hline ABI Share & 1364 & 11.51 & 5.86 & 0.38 & 31.54 & 7643 & 11.71 & 6.14 & 0.00 & 33.33 \\
\hline Prov-age & 1364 & 3.32 & 0.55 & 1.32 & 3.76 & 7689 & 3.20 & 0.52 & 0.41 & 3.76 \\
\hline Fund-age & 1364 & 1.71 & 0.60 & 0.41 & 3.44 & 7689 & 1.62 & 0.68 & 0.41 & 3.44 \\
\hline $\mathrm{HHI}$ & 1364 & 6.80 & 2.41 & 4.90 & 35.60 & 7689 & 7.13 & 4.35 & 4.33 & 100.00 \\
\hline $\mathrm{CR}$ & 1364 & 32.13 & 6.81 & 26.21 & 72.03 & 7689 & 32.69 & 9.83 & 23.23 & 100.00 \\
\hline
\end{tabular}


Table 3. The cross-section results for the basic specification, panel A, with the concentration ratio (CR), Panel B and Hirschmann-Herfindahl index (HHI), Panel C. P-values are shown in parenthesis. $* * *: 1 \%$ significance; $* *: 5 \%$ significance and *: $10 \%$ significance.

\begin{tabular}{|c|c|c|c|c|c|c|c|c|c|c|c|c|}
\hline & \multicolumn{4}{|c|}{ Panel A } & \multicolumn{4}{|c|}{ Panel B } & \multicolumn{4}{|c|}{ Panel C } \\
\hline & R-Tbill & R-PPB & $\mathrm{M}^{2}$ & Sharpe & R-Tbill & R-PPB & $\mathrm{M}^{2}$ & Sharpe & R-Tbill & R-PPB & $\mathrm{M}^{2}$ & Sharpe \\
\hline \multirow[t]{2}{*}{ Constant } & 9.689 & -3.044 & -0.542 & $3.262^{* * *}$ & 5.000 & -2.368 & -0.087 & 2.513 & 7.653 & -2.502 & -0.077 & $2.927 *$ \\
\hline & $(0.142)$ & $(0.369)$ & $(0.834)$ & $(0.048)$ & $(0.438)$ & $(0.446)$ & $(0.972)$ & $(0.115)$ & $(0.239)$ & $(0.437)$ & $(0.975)$ & $(0.071)$ \\
\hline \multirow[t]{2}{*}{ Size } & $-0.786^{*}$ & 0.225 & 0.163 & $-0.145^{*}$ & -0.533 & 0.147 & 0.094 & -0.104 & -0.515 & 0.152 & 0.101 & -0.101 \\
\hline & $(0.093)$ & $(0.160)$ & $(0.252)$ & $(0.093)$ & $(0.209)$ & $(0.135)$ & $(0.352)$ & $(0.202)$ & $(0.241)$ & $(0.119)$ & $(0.312)$ & $(0.227)$ \\
\hline \multirow{3}{*}{$\begin{array}{l}\text { Share-in- } \\
\text { ABI }\end{array}$} & & & & & & & & & & & & \\
\hline & $0.233 * * *$ & -0.063 & -0.054 & $0.038^{* *}$ & & & & & & & & \\
\hline & $(0.003)$ & $(0.323)$ & $(0.345)$ & $(0.031)$ & & & & & & & & \\
\hline \multirow[t]{2}{*}{ ABI-share } & -0.034 & 0.001 & -0.001 & -0.008 & 0.002 & -0.008 & -0.010 & -0.002 & 0.004 & -0.009 & -0.010 & -0.002 \\
\hline & $(0.400)$ & $(0.940)$ & $(0.944)$ & $(0.321)$ & $(0.960)$ & $(0.485)$ & $(0.383)$ & $(0.800)$ & $(0.917)$ & $(0.460)$ & $(0.374)$ & $(0.788)$ \\
\hline \multirow[t]{2}{*}{ Prov-age } & 1.398 & 0.830 & 0.818 & 0.097 & 1.380 & 0.857 & 0.846 & 0.093 & 1.319 & 0.852 & 0.837 & 0.084 \\
\hline & $(0.496)$ & $(0.314)$ & $(0.259)$ & $(0.817)$ & $(0.505)$ & $(0.306)$ & $(0.248)$ & $(0.826)$ & $(0.528)$ & $(0.310)$ & $(0.252)$ & $(0.844)$ \\
\hline \multirow[t]{2}{*}{ Fund-age } & $-6.265 * * *$ & 1.047 & 0.101 & $-1.376^{* * *}$ & $-5.968 * * *$ & 0.904 & -0.035 & $-1.326 * * *$ & $-5.846^{* * *}$ & 0.933 & 0.003 & $-1.308 * * *$ \\
\hline & $(0.001)$ & $(0.125)$ & $(0.862)$ & $(0.000)$ & $(0.001)$ & $(0.127)$ & $(0.945)$ & $(0.000)$ & $(0.002)$ & $(0.110)$ & (0.995) & $(0.000)$ \\
\hline \multirow[t]{2}{*}{ ALC } & 0.504 & $0.891^{* * *}$ & 0.815 & -0.056 & 0.865 & $0.935 * * *$ & 0.883 & -0.000 & 0.474 & $0.901^{* * *}$ & 0.824 & -0.059 \\
\hline & $(0.607)$ & $(0.013)$ & $(0.146)$ & $(0.866)$ & $(0.401)$ & $(0.004)$ & $(0.102)$ & $(1.000)$ & $(0.595)$ & $(0.005)$ & $(0.120)$ & $(0.853)$ \\
\hline \multirow[t]{2}{*}{ EM-E } & $7.667 * * *$ & -0.321 & 0.024 & 0.213 & $6.725 * * *$ & -0.264 & 0.031 & 0.064 & $7.285^{* * *}$ & -0.222 & 0.109 & 0.149 \\
\hline & $(0.000)$ & (0.599) & $(0.971)$ & $(0.482)$ & $(0.000)$ & $(0.705)$ & $(0.967)$ & $(0.815)$ & $(0.000)$ & $(0.735)$ & (0.883) & $(0.621)$ \\
\hline \multirow[t]{2}{*}{ E-I } & $1.767^{*}$ & -0.193 & -0.296 & -0.218 & $2.352^{* *}$ & -0.173 & -0.240 & -0.127 & $1.839^{*}$ & -0.210 & -0.310 & -0.204 \\
\hline & $(0.083)$ & $(0.697)$ & $(0.531)$ & $(0.342)$ & $(0.046)$ & $(0.714)$ & $(0.597)$ & $(0.629)$ & $(0.080)$ & $(0.638)$ & $(0.467)$ & $(0.404)$ \\
\hline \multirow[t]{2}{*}{ UK-E } & -0.525 & -0.146 & -0.486 & $-0.484 * *$ & -0.332 & -0.058 & -0.380 & $-0.456^{* *}$ & -0.632 & -0.115 & -0.459 & $-0.500 * *$ \\
\hline & $(0.583)$ & $(0.811)$ & $(0.443)$ & $(0.017)$ & $(0.738)$ & $(0.918)$ & $(0.521)$ & $(0.039)$ & $(0.507)$ & $(0.832)$ & $(0.423)$ & $(0.020)$ \\
\hline \multirow[t]{2}{*}{$\mathrm{CR}$} & & & & & $0.122 * * *$ & -0.016 & -0.010 & $0.019^{* *}$ & & & & \\
\hline & & & & & $(0.001)$ & $(0.501)$ & $(0.636)$ & $(0.016)$ & & & & \\
\hline \multirow[t]{2}{*}{ HHI } & & & & & & & & & $0.215 * * *$ & -0.057 & -0.049 & $0.035^{* *}$ \\
\hline & & & & & & & & & $(0.000)$ & $(0.301)$ & $(0.369)$ & $(0.012)$ \\
\hline $\mathrm{R}^{2}$ & 0.113 & 0.034 & 0.020 & 0.114 & 0.113 & 0.033 & 0.019 & 0.114 & 0.111 & 0.033 & 0.020 & 0.113 \\
\hline F & 13.797 & 5.878 & 9.265 & 15.420 & 14.639 & 6.047 & 3.525 & 12.837 & 15.159 & 5.625 & 6.420 & 12.927 \\
\hline p-value & 0.000 & 0.000 & 0.000 & 0.000 & 0.000 & 0.000 & 0.004 & 0.000 & 0.000 & 0.000 & 0.000 & 0.000 \\
\hline Funds & 4194 & 4194 & 4194 & 4194 & 4194 & 4194 & 4194 & 4194 & 4194 & 4194 & 4194 & 4194 \\
\hline
\end{tabular}


Table 4. The cross-section results for the specification with interactive terms and the Bear-born dummy, Panel A, and the Bull-born dummy, Panel B. P-values are shown in parenthesis. ***: $1 \%$ significance; **: $5 \%$ significance and *: $10 \%$ significance.

\begin{tabular}{|c|c|c|c|c|c|c|c|c|}
\hline \multirow[b]{3}{*}{ Constant } & \multicolumn{4}{|c|}{ Panel A } & \multicolumn{4}{|c|}{ Panel B } \\
\hline & R-Tbill & R-PPB & $\mathbf{M}^{2}$ & Sharpe & R-Tbill & R-PPB & $M^{2}$ & Sharpe \\
\hline & $\begin{array}{l}8.291 \\
(0.182)\end{array}$ & $\begin{array}{l}-3.661 \\
(0.210)\end{array}$ & $\begin{array}{l}-1.078 \\
(0.668)\end{array}$ & $\begin{array}{l}4.059^{* *} \\
(0.020)\end{array}$ & $\begin{array}{l}8.601 \\
(0.104)\end{array}$ & $\begin{array}{l}-3.406 \\
(0.259)\end{array}$ & $\begin{array}{l}-0.779 \\
(0.774)\end{array}$ & $\begin{array}{l}4.092 * * * \\
(0.009)\end{array}$ \\
\hline Size & $\begin{array}{l}-0.816^{*} \\
(0.085)\end{array}$ & $\begin{array}{l}0.216 \\
(0.134)\end{array}$ & $\begin{array}{l}0.141 \\
(0.257)\end{array}$ & $\begin{array}{l}-0.153^{*} \\
(0.091)\end{array}$ & $\begin{array}{l}-0.713 \\
(0.109)\end{array}$ & $\begin{array}{l}0.223 \\
(0.143)\end{array}$ & $\begin{array}{l}0.160 \\
(0.235)\end{array}$ & $\begin{array}{l}-0.132 \\
(0.118)\end{array}$ \\
\hline Share-in-ABI & $\begin{array}{l}0.256 * * * \\
(0.005)\end{array}$ & $\begin{array}{l}-0.057 \\
(0.351)\end{array}$ & $\begin{array}{l}-0.039 \\
(0.465)\end{array}$ & $\begin{array}{l}0.042 * * \\
(0.028)\end{array}$ & $\begin{array}{l}0.196 * * \\
(0.011)\end{array}$ & $\begin{array}{l}-0.064 \\
(0.302)\end{array}$ & $\begin{array}{l}-0.052 \\
(0.334)\end{array}$ & $\begin{array}{l}0.030^{*} \\
(0.067)\end{array}$ \\
\hline ABI-share & $\begin{array}{l}-0.042 \\
(0.330)\end{array}$ & $\begin{array}{l}0.001 \\
(0.959)\end{array}$ & $\begin{array}{l}-0.000 \\
(0.984)\end{array}$ & $\begin{array}{l}-0.003 \\
(0.707)\end{array}$ & $\begin{array}{l}-0.035 \\
(0.426)\end{array}$ & $\begin{array}{l}0.004 \\
(0.861)\end{array}$ & $\begin{array}{l}0.003 \\
(0.856)\end{array}$ & $\begin{array}{l}-0.002 \\
(0.835)\end{array}$ \\
\hline Prov-age & $\begin{array}{l}1.319 \\
(0.507)\end{array}$ & $\begin{array}{l}0.755 \\
(0.332)\end{array}$ & $\begin{array}{l}0.732 \\
(0.278)\end{array}$ & $\begin{array}{l}0.086 \\
(0.834)\end{array}$ & $\begin{array}{l}1.510 \\
(0.413)\end{array}$ & $\begin{array}{l}0.810 \\
(0.324)\end{array}$ & $\begin{array}{l}0.810 \\
(0.273)\end{array}$ & $\begin{array}{l}0.120 \\
(0.749)\end{array}$ \\
\hline Fund-age & $\begin{array}{l}-5.350^{* * * *} \\
(0.000)\end{array}$ & $\begin{array}{l}1.472 * * \\
(0.026)\end{array}$ & $\begin{array}{l}0.476 \\
(0.396)\end{array}$ & $\begin{array}{l}-1.844 * * * \\
(0.000)\end{array}$ & $\begin{array}{l}-4.665^{* * * *} \\
(0.001)\end{array}$ & $\begin{array}{l}1.347 * * \\
(0.043)\end{array}$ & $\begin{array}{l}0.417 \\
(0.464)\end{array}$ & $\begin{array}{l}-1.680 * * * \\
(0.000)\end{array}$ \\
\hline ALC & $\begin{array}{l}2.142 \\
(0.473)\end{array}$ & $\begin{array}{l}2.421 * \\
(0.082)\end{array}$ & $\begin{array}{l}2.987 * \\
(0.083)\end{array}$ & $\begin{array}{l}0.448 \\
(0.710)\end{array}$ & $\begin{array}{l}4.691^{*} \\
(0.055)\end{array}$ & $\begin{array}{l}2.625^{*} \\
(0.054)\end{array}$ & $\begin{array}{l}3.468 * * \\
(0.047)\end{array}$ & $\begin{array}{l}0.967 \\
(0.355)\end{array}$ \\
\hline EM-E & $\begin{array}{l}14.782 * * \\
(0.041)\end{array}$ & $\begin{array}{l}0.305 \\
(0.906)\end{array}$ & $\begin{array}{l}2.228 \\
(0.270)\end{array}$ & $\begin{array}{l}-0.650 \\
(0.477)\end{array}$ & $\begin{array}{l}14.597 * * \\
(0.037)\end{array}$ & $\begin{array}{l}1.123 \\
(0.640)\end{array}$ & $\begin{array}{l}3.067 \\
(0.114)\end{array}$ & $\begin{array}{l}-0.798 \\
(0.382)\end{array}$ \\
\hline E-I & $\begin{array}{l}4.935^{*} \\
(0.056)\end{array}$ & $\begin{array}{l}1.214 \\
(0.514)\end{array}$ & $\begin{array}{l}0.952 \\
(0.579)\end{array}$ & $\begin{array}{l}-1.112 * \\
(0.050)\end{array}$ & $\begin{array}{l}6.545 * * \\
(0.016)\end{array}$ & $\begin{array}{l}1.337 \\
(0.487)\end{array}$ & $\begin{array}{l}1.250 \\
(0.484)\end{array}$ & $\begin{array}{l}-0.783 \\
(0.149)\end{array}$ \\
\hline UK-E & $\begin{array}{l}-1.761 \\
(0.575)\end{array}$ & $\begin{array}{l}-1.495 \\
(0.555)\end{array}$ & $\begin{array}{l}-2.165 \\
(0.379)\end{array}$ & $\begin{array}{l}-1.834 * * * \\
(0.000)\end{array}$ & $\begin{array}{l}0.607 \\
(0.855)\end{array}$ & $\begin{array}{l}-1.327 \\
(0.623)\end{array}$ & $\begin{array}{l}-1.741 \\
(0.504)\end{array}$ & $\begin{array}{l}-1.348 * * \\
(0.010)\end{array}$ \\
\hline Fund-age*ALC & $\begin{array}{l}-0.976 \\
(0.466)\end{array}$ & $\begin{array}{l}-0.971 \\
(0.201)\end{array}$ & $\begin{array}{l}-1.351 * \\
(0.088)\end{array}$ & $\begin{array}{l}-0.306 \\
(0.588)\end{array}$ & $\begin{array}{l}-2.074 * \\
(0.064)\end{array}$ & $\begin{array}{l}-1.015 \\
(0.164)\end{array}$ & $\begin{array}{l}-1.513 * \\
(0.056)\end{array}$ & $\begin{array}{l}-0.535 \\
(0.278)\end{array}$ \\
\hline Fund-age*EM- & & & & & & & & \\
\hline $\mathrm{E}$ & $\begin{array}{l}-5.073 \\
(0.214)\end{array}$ & $\begin{array}{l}-0.590 \\
(0.679)\end{array}$ & $\begin{array}{l}-1.756 \\
(0.117)\end{array}$ & $\begin{array}{l}0.517 \\
(0.308)\end{array}$ & $\begin{array}{l}-4.055 \\
(0.288)\end{array}$ & $\begin{array}{l}-0.948 \\
(0.468)\end{array}$ & $\begin{array}{l}-2.025^{*} \\
(0.064)\end{array}$ & $\begin{array}{l}0.782 \\
(0.113)\end{array}$ \\
\hline Fund-age*I-E & $\begin{array}{l}-1.910^{*} \\
(0.057)\end{array}$ & $\begin{array}{l}-0.928 \\
(0.278)\end{array}$ & $\begin{array}{l}-0.836 \\
(0.295)\end{array}$ & $\begin{array}{l}0.525^{* *} \\
(0.028)\end{array}$ & $\begin{array}{l}-2.550 * * \\
(0.019)\end{array}$ & $\begin{array}{l}-0.900 \\
(0.316)\end{array}$ & $\begin{array}{l}-0.874 \\
(0.298)\end{array}$ & $\begin{array}{l}0.385^{*} \\
(0.080)\end{array}$ \\
\hline $\begin{array}{l}\text { Fund-age*UK- } \\
\text { E }\end{array}$ & $\begin{array}{l}0.701 \\
(0.612)\end{array}$ & $\begin{array}{l}0.698 \\
(0.545)\end{array}$ & $\begin{array}{l}0.887 \\
(0.428)\end{array}$ & $\begin{array}{l}0.778 * * * \\
(0.000)\end{array}$ & $\begin{array}{l}-0.301 \\
(0.838)\end{array}$ & $\begin{array}{l}0.687 \\
(0.582)\end{array}$ & $\begin{array}{l}0.770 \\
(0.519)\end{array}$ & $\begin{array}{l}0.565^{* * * *} \\
(0.010)\end{array}$ \\
\hline Bear-born & $\begin{array}{l}0.919 \\
(0.518)\end{array}$ & $\begin{array}{l}1.172 * * \\
(0.012)\end{array}$ & $\begin{array}{l}1.324 * * * \\
(0.001)\end{array}$ & $\begin{array}{l}0.042 \\
(0.879)\end{array}$ & & & & \\
\hline Bull-born & & & & & $\begin{array}{l}-5.468 * * * \\
(0.000)\end{array}$ & $\begin{array}{l}-0.169 \\
(0.641)\end{array}$ & $\begin{array}{l}-0.751 * * \\
(0.027)\end{array}$ & $\begin{array}{l}-1.150 * * * \\
(0.000)\end{array}$ \\
\hline $\mathrm{R}^{2}$ & 0.120 & 0.053 & 0.045 & 0.122 & 0.176 & 0.043 & 0.038 & 0.179 \\
\hline $\mathrm{F}$ & 26.280 & 13.122 & 13.074 & 74.203 & 67.141 & 19.655 & 12.526 & 46.835 \\
\hline p-value & 0.000 & 0.000 & 0.000 & 0.000 & 0.000 & 0.000 & 0.000 & 0.000 \\
\hline Funds & 4194 & 4194 & 4194 & 4194 & 4194 & 4194 & 4194 & 4194 \\
\hline
\end{tabular}


Table 5. The cross-section regressions for the specifications with interactive terms and the Bear-born dummy, Panel A, and the Bull-born dummy, Panel B, using arithmetic returns. P-values are shown in parenthesis. ***: $1 \%$ significance; **: $5 \%$ significance and *: $10 \%$ significance.

\begin{tabular}{|c|c|c|c|c|c|c|c|c|}
\hline & \multicolumn{4}{|c|}{ Panel A } & \multicolumn{4}{|c|}{ Panel B } \\
\hline & R-Tbill & R-PPB & $\mathrm{M}^{2}$ & Sharpe & R-Tbill & R-PPB & $\mathrm{M}^{2}$ & Sharpe \\
\hline \multirow[t]{2}{*}{ Constant } & 8.900 & -3.617 & -1.117 & $4.239 * *$ & $9.302 *$ & -3.389 & -0.833 & $4.277 * * *$ \\
\hline & $(0.134)$ & $(0.215)$ & $(0.656)$ & $(0.014)$ & $(0.063)$ & $(0.257)$ & $(0.757)$ & $(0.006)$ \\
\hline \multirow[t]{2}{*}{ Size } & $-0.820 *$ & $0.244^{*}$ & 0.156 & $-0.152 *$ & $-0.713 *$ & 0.249 & 0.173 & -0.131 \\
\hline & $(0.072)$ & $(0.094)$ & $(0.208)$ & $(0.085)$ & $(0.094)$ & $(0.103)$ & $(0.194)$ & $(0.110)$ \\
\hline \multirow[t]{2}{*}{ Share-in-ABI } & $0.280 * * *$ & -0.064 & -0.042 & $0.043 * *$ & $0.217 * * *$ & -0.069 & -0.055 & $0.031^{*}$ \\
\hline & $(0.002)$ & $(0.304)$ & $(0.426)$ & $(0.021)$ & $(0.004)$ & $(0.270)$ & $(0.311)$ & $(0.051)$ \\
\hline \multirow[t]{2}{*}{ ABI-share } & -0.046 & 0.014 & 0.006 & -0.003 & -0.038 & 0.016 & 0.009 & -0.002 \\
\hline & $(0.261)$ & $(0.470)$ & $(0.713)$ & $(0.692)$ & $(0.356)$ & $(0.418)$ & $(0.585)$ & $(0.828)$ \\
\hline \multirow[t]{2}{*}{ Prov-age } & 1.307 & 0.723 & 0.716 & 0.086 & 1.519 & 0.771 & 0.790 & 0.120 \\
\hline & $(0.494)$ & $(0.348)$ & $(0.285)$ & $(0.832)$ & $(0.389)$ & $(0.340)$ & $(0.280)$ & $(0.742)$ \\
\hline \multirow[t]{2}{*}{ Fund-age } & $-5.547 * * *$ & $1.477 * *$ & 0.499 & $-1.870 * * *$ & $-4.897 * * *$ & $1.353 * *$ & 0.439 & $-1.710 * * *$ \\
\hline & $(0.000)$ & $(0.026)$ & $(0.372)$ & $(0.000)$ & $(0.000)$ & $(0.045)$ & $(0.440)$ & $(0.000)$ \\
\hline \multirow[t]{2}{*}{ ALC } & 2.083 & 2.256 & $2.871^{*}$ & 0.440 & $4.730^{*}$ & $2.404^{*}$ & $3.319^{*}$ & 0.962 \\
\hline & $(0.483)$ & $(0.119)$ & $(0.089)$ & $(0.714)$ & $(0.050)$ & $(0.089)$ & $(0.052)$ & $(0.356)$ \\
\hline \multirow[t]{2}{*}{ EM-E } & $22.038 * * *$ & -0.018 & 2.128 & -0.207 & $22.138 * * *$ & 0.734 & 2.928 & -0.334 \\
\hline & $(0.002)$ & $(0.995)$ & $(0.304)$ & $(0.814)$ & $(0.001)$ & $(0.772)$ & $(0.138)$ & $(0.703)$ \\
\hline \multirow[t]{2}{*}{ E-I } & $7.197 * * *$ & 0.942 & 0.840 & $-0.920 *$ & $8.867 * * *$ & 1.030 & 1.117 & -0.590 \\
\hline & $(0.005)$ & $(0.615)$ & $(0.623)$ & $(0.098)$ & $(0.001)$ & $(0.593)$ & $(0.530)$ & $(0.269)$ \\
\hline \multirow[t]{2}{*}{ UK-E } & -0.035 & -1.787 & -2.312 & $-1.667 * * *$ & 2.417 & -1.669 & -1.918 & $-1.180 * *$ \\
\hline & $(0.991)$ & $(0.481)$ & $(0.348)$ & $(0.001)$ & $(0.448)$ & $(0.535)$ & $(0.461)$ & $(0.020)$ \\
\hline \multirow[t]{2}{*}{ Fund-age*ALC } & -0.626 & -1.031 & $-1.365^{*}$ & -0.255 & -1.751 & -1.055 & $-1.515^{*}$ & -0.485 \\
\hline & $(0.635)$ & $(0.191)$ & $(0.078)$ & $(0.649)$ & $(0.105)$ & $(0.165)$ & $(0.051)$ & $(0.323)$ \\
\hline \multirow[t]{2}{*}{ Fund-age*EM-E } & $-6.879 *$ & -0.390 & -1.670 & 0.462 & $-5.975^{*}$ & -0.733 & $-1.931 *$ & 0.718 \\
\hline & $(0.079)$ & $(0.795)$ & $(0.144)$ & $(0.344)$ & $(0.100)$ & $(0.594)$ & $(0.082)$ & $(0.129)$ \\
\hline \multirow[t]{2}{*}{ Fund-age*I-E } & $-2.160 * *$ & -0.792 & -0.775 & $0.532 * *$ & $-2.797 * * *$ & -0.757 & -0.807 & $0.393^{*}$ \\
\hline & $(0.028)$ & $(0.357)$ & $(0.331)$ & $(0.025)$ & $(0.008)$ & $(0.401)$ & $(0.335)$ & $(0.072)$ \\
\hline \multirow[t]{2}{*}{ Fund-age*UK-E } & 0.452 & 0.808 & 0.949 & $0.776^{* * * *}$ & -0.564 & 0.812 & 0.842 & $0.563 * * *$ \\
\hline & $(0.737)$ & $(0.484)$ & $(0.397)$ & $(0.000)$ & $(0.690)$ & $(0.514)$ & $(0.481)$ & $(0.009)$ \\
\hline \multirow[t]{2}{*}{ Bear-born } & 1.338 & $1.059 * *$ & $1.258 * * *$ & 0.070 & & & & \\
\hline & $(0.329)$ & $(0.031)$ & $(0.002)$ & $(0.796)$ & & & & \\
\hline \multirow[t]{2}{*}{ Bull-born } & & & & & $-5.585 * * *$ & -0.072 & $-0.691 * *$ & $-1.149 * * *$ \\
\hline & & & & & $(0.000)$ & $(0.845)$ & $(0.039)$ & $(0.000)$ \\
\hline $\mathrm{R}^{2}$ & 0.163 & 0.053 & 0.044 & 0.127 & 0.218 & 0.045 & 0.037 & 0.185 \\
\hline $\mathrm{F}$ & 35.588 & 9.111 & 14.783 & 90.676 & 77.707 & 15.273 & 16.054 & 56.493 \\
\hline p-value & 0.000 & 0.000 & 0.000 & 0.000 & 0.000 & 0.000 & 0.000 & 0.000 \\
\hline Funds & 4194 & 4194 & 4194 & 4194 & 4194 & 4194 & 4194 & 4194 \\
\hline
\end{tabular}




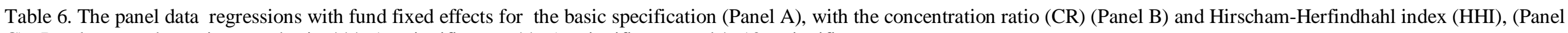
C). P-values are shown in parenthesis. ***: $1 \%$ significance; $* *: 5 \%$ significance and $*: 10 \%$ significance

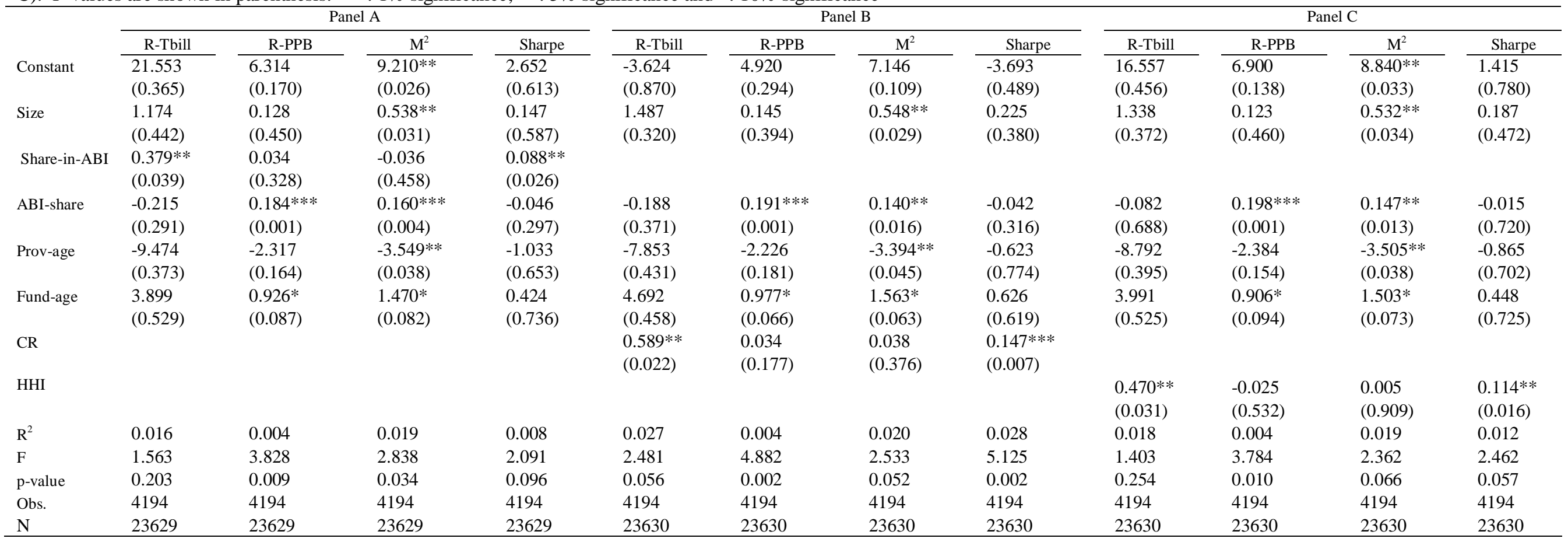




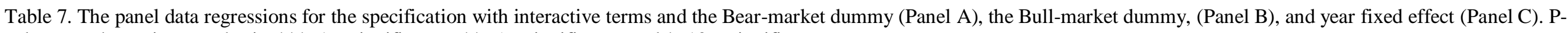
values are shown in parenthesis. $* * *: 1 \%$ significance; $* *: 5 \%$ significance and $*: 10 \%$ significance.

\begin{tabular}{|c|c|c|c|c|c|c|c|c|c|c|c|c|}
\hline & \multicolumn{4}{|c|}{ Panel A: Bear-market } & \multicolumn{4}{|c|}{ Panel B: Bull-market } & \multicolumn{4}{|c|}{ Panel C: Year Fixed Effects } \\
\hline & R-Tbill & R-PPB & $\mathrm{M}^{2}$ & Sharpe & R-Tbill & R-PPB & $\mathrm{M}^{2}$ & Sharpe & R-Tbill & R-PPB & $\mathrm{M}^{2}$ & Sharpe \\
\hline \multirow[t]{2}{*}{ Constant } & $28.277 * *$ & 5.379 & $7.958 *$ & 3.927 & $30.516^{*}$ & 5.527 & 6.526 & 4.966 & 5.704 & 2.994 & 1.461 & 0.458 \\
\hline & $(0.024)$ & $(0.231)$ & $(0.053)$ & $(0.155)$ & $(0.085)$ & $(0.215)$ & $(0.144)$ & $(0.190)$ & $(0.419)$ & $(0.647)$ & $(0.777)$ & $(0.698)$ \\
\hline \multirow[t]{2}{*}{ Size } & 1.161 & 0.131 & $0.537 * *$ & 0.148 & 2.178 & 0.139 & $0.398 *$ & 0.388 & 0.016 & 0.022 & 0.123 & 0.034 \\
\hline & $(0.145)$ & $(0.460)$ & $(0.039)$ & $(0.292)$ & $(0.165)$ & $(0.449)$ & $(0.085)$ & $(0.181)$ & $(0.938)$ & $(0.861)$ & $(0.442)$ & $(0.432)$ \\
\hline \multirow[t]{2}{*}{ Share-in-ABI } & $0.161^{*}$ & 0.037 & -0.031 & $0.046^{*}$ & $0.293 * *$ & 0.033 & -0.009 & $0.059^{*}$ & $0.102^{* *}$ & 0.018 & -0.017 & 0.019 \\
\hline & $(0.096)$ & $(0.298)$ & $(0.552)$ & $(0.057)$ & $(0.035)$ & $(0.341)$ & $(0.839)$ & $(0.063)$ & $(0.041)$ & $(0.513)$ & $(0.626)$ & $(0.229)$ \\
\hline \multirow[t]{2}{*}{ ABI-share } & -0.200 & $0.212^{* * *}$ & $0.166^{* * *}$ & -0.038 & -0.370 & $0.212^{* * * *}$ & $0.184 * * *$ & -0.076 & 0.003 & $0.228 * * *$ & $0.221 * * *$ & -0.003 \\
\hline & $(0.282)$ & $(0.000)$ & $(0.005)$ & $(0.197)$ & $(0.252)$ & $(0.000)$ & $(0.007)$ & $(0.123)$ & $(0.979)$ & $(0.000)$ & $(0.008)$ & $(0.896)$ \\
\hline \multirow[t]{2}{*}{ Prov-age } & $-8.610^{*}$ & -2.109 & $-3.172 *$ & -0.908 & $-16.002 * *$ & -2.163 & -2.202 & -2.635 & 0.450 & -0.858 & -0.029 & 0.486 \\
\hline & $(0.085)$ & $(0.206)$ & $(0.061)$ & $(0.434)$ & $(0.047)$ & $(0.197)$ & $(0.234)$ & $(0.126)$ & $(0.883)$ & $(0.721)$ & $(0.987)$ & $(0.392)$ \\
\hline \multirow[t]{2}{*}{ Fund-age } & 7.143 & 0.457 & -0.335 & 1.236 & $5.632 * *$ & 0.490 & -0.518 & 1.056 & 2.410 & 0.726 & -0.977 & 0.440 \\
\hline & $(0.134)$ & $(0.741)$ & $(0.743)$ & $(0.360)$ & $(0.036)$ & $(0.729)$ & $(0.626)$ & $(0.317)$ & $(0.557)$ & $(0.562)$ & $(0.216)$ & $(0.566)$ \\
\hline \multirow[t]{2}{*}{ Fund-age*ALC } & -3.714 & 1.306 & $3.017 * * *$ & -0.773 & 0.422 & 1.288 & $2.895 * * *$ & 0.002 & -0.946 & 1.232 & $2.545^{* * * *}$ & -0.245 \\
\hline & $(0.140)$ & $(0.239)$ & $(0.000)$ & $(0.261)$ & $(0.938)$ & $(0.238)$ & $(0.000)$ & $(0.998)$ & $(0.826)$ & $(0.259)$ & $(0.001)$ & $(0.761)$ \\
\hline \multirow[t]{2}{*}{ Fund-age*EM-E } & $15.668^{*}$ & $4.043^{* *}$ & $7.609 * * *$ & $1.786^{* * *}$ & 19.806 & $3.991 * *$ & $7.777 * * *$ & $2.430 * *$ & 15.567 & $3.541^{* * *}$ & $6.907 * * *$ & 1.630 \\
\hline & $(0.082)$ & $(0.011)$ & $(0.001)$ & $(0.048)$ & $(0.193)$ & $(0.013)$ & $(0.001)$ & $(0.032)$ & $(0.247)$ & $(0.048)$ & $(0.001)$ & $(0.188)$ \\
\hline Fund-age*I-E & -4.006 & 1.064 & $2.302^{* * * *}$ & -0.946 & 0.260 & 1.046 & $2.165^{* * *}$ & -0.141 & -0.493 & 1.112 & $2.319 * * *$ & -0.326 \\
\hline \multirow[t]{2}{*}{ Fund-age*UK-E } & -3.623 & -0.694 & 1.016 & -0.964 & -0.706 & -0.710 & 0.953 & -0.428 & -0.995 & -0.658 & 0.867 & -0.485 \\
\hline & $(0.255)$ & $(0.705)$ & $(0.414)$ & $(0.366)$ & $(0.918)$ & $(0.699)$ & $(0.468)$ & $(0.705)$ & $(0.876)$ & $(0.721)$ & $(0.501)$ & $(0.662)$ \\
\hline \multirow[t]{2}{*}{ Bear-market } & $-38.020 * * *$ & 0.234 & 0.557 & $-6.873 * * *$ & & & & & & & & \\
\hline & $(0.000)$ & $(0.541)$ & $(0.444)$ & $(0.000)$ & & & & & & & & \\
\hline \multirow[t]{2}{*}{ Bull-market } & & & & & $15.884 * * *$ & 0.121 & $-2.123 * * *$ & $3.728 * * *$ & & & & \\
\hline & & & & & $(0.006)$ & $(0.820)$ & $(0.002)$ & $(0.000)$ & & & & \\
\hline $\mathrm{R}^{2}$ & 0.526 & 0.007 & 0.025 & 0.448 & 0.127 & 0.006 & 0.039 & 0.167 & 0.637 & 0.039 & 0.086 & 0.590 \\
\hline $\mathrm{F}$ & 64.167 & 12.623 & 5.532 & 55.468 & 6.520 & 9.013 & 11.729 & 9.405 & $1.005 \mathrm{e}+08$ & $2.372 \mathrm{e}+06$ & $6.4765 e+05$ & $6.209 \mathrm{e}+07$ \\
\hline \multirow[t]{2}{*}{ p-value } & 0.000 & 0.000 & 0.000 & 0.000 & 0.000 & 0.000 & 0.000 & 0.000 & 0.000 & 0.000 & 0.000 & 0.000 \\
\hline & 4194 & 4194 & 4194 & 4194 & 4194 & 4194 & 4194 & 4194 & 4194 & 4194 & 4194 & 4194 \\
\hline Obs. & 23629 & 23629 & 23629 & 23629 & 23629 & 23629 & 23629 & 23629 & 23629 & 23629 & 23629 & 23629 \\
\hline
\end{tabular}


Appendix 1. Pairwise correlations between the independent variables (in bold are correlations with an absolute value above 0.4).

\begin{tabular}{|c|c|c|c|c|c|c|c|c|c|}
\hline \multicolumn{10}{|c|}{ Panel A: Cross-Section data } \\
\hline & Size & Share-in-ABI & ABI Share & Prov-age & Fund-age & $\mathrm{CR}$ & HHI & Bear-born & Bull-born \\
\hline Size & 1 & & & & & & & & \\
\hline Share-in-ABI & 0.524 & 1 & & & & & & & \\
\hline ABI Share & -0.187 & 0.077 & 1 & & & & & & \\
\hline Prov-age & 0.398 & 0.294 & -0.064 & 1 & & & & & \\
\hline Fund-age & -0.394 & 0.116 & 0.140 & 0.173 & 1 & & & & \\
\hline CR & 0.098 & 0.666 & -0.102 & 0.079 & 0.120 & 1 & & & \\
\hline HHI & 0.092 & 0.692 & -0.117 & 0.090 & 0.137 & 0.905 & 1 & & \\
\hline Bear-born & 0.079 & -0.061 & 0.016 & 0.008 & -0.169 & -0.086 & -0.089 & 1 & \\
\hline Bull-born & 0.031 & -0.028 & 0.017 & 0.030 & 0.002 & -0.072 & -0.061 & -0.534 & 1 \\
\hline
\end{tabular}

Panel B: Panel data

\begin{tabular}{|c|c|c|c|c|c|c|c|c|c|}
\hline & Size & Share-in-ABI & ABI Share & Prov-age & Fund-age & $\mathrm{CR}$ & $\mathrm{HHI}$ & Bear-market & Bull-market \\
\hline Size & 1 & & & & & & & & \\
\hline Share-in-ABI & 0.292 & 1 & & & & & & & \\
\hline ABI Share & -0.176 & 0.100 & 1 & & & & & & \\
\hline Prov-age & 0.484 & 0.137 & -0.073 & 1 & & & & & \\
\hline Fund-age & -0.035 & 0.031 & 0.029 & 0.091 & 1 & & & & \\
\hline $\mathrm{CR}$ & -0.036 & 0.711 & 0.010 & -0.052 & -0.036 & 1 & & & \\
\hline HHI & -0.040 & 0.759 & -0.038 & -0.050 & -0.026 & 0.851 & 1 & & \\
\hline Bear-market & 0.032 & -0.056 & 0.023 & 0.020 & -0.046 & -0.086 & -0.067 & 1 & \\
\hline Bull-market & -0.153 & 0.038 & 0.042 & -0.014 & 0.015 & 0.043 & 0.027 & -0.471 & 1 \\
\hline
\end{tabular}

